\title{
3D characterisation of the thermohaline structure in the southwestern tropical Atlantic derived from functional data analysis of in situ profiles
}

\author{
Assunção Ramilla V. 1, 2, 3, ${ }^{*}$, Silva Alex C. ${ }^{1}$, Roy Amedee ${ }^{2}$, Bourlès Bernard ${ }^{4}$, \\ Henrique S. Silva Carlos ${ }^{5}$, Ternon Jean-Francois ${ }^{2}$, Araujo Moacyr ${ }^{1,6}$, Bertrand Arnaud ${ }^{1,2,5}$
}

${ }^{1}$ Laboratório de Oceanografia Física Estuarina e Costeira, Depto. Oceanografia, UFPE, Recife-PE, Brazil

2 Institut de recherche pour le développement (IRD), MARBEC, Université Montpellier, CNRS, Ifremer, IRD, Sète, France

3 IRD, UMR 6539 LEMAR IFREMER/IRD/CNRS/UBO, Technopole Brest Iroise, 29280 Plouzané, France

${ }^{4}$ Institut de recherche pour le développement (IRD), Délégation Régionale Ouest, IMAGO, Plouzané,

France

${ }^{5}$ Universidade Federal Rural de Pernambuco, Recife-PE, Brazil

${ }^{6}$ Brazilian Research network on Global Climate Change, Rede CLIMA, São José dos Campos-SP, Brazil

* Corresponding author : Ramilla V. Assunção, email address : ramillavieira@hotmail.com

\begin{abstract}
:
The dynamic of the thermohaline structure of the upper ocean, which depends on ocean-atmosphere interactions, drives most near surface oceanic processes, including the control of gases and heat fluxes, and nutrient availability in the photic layer. The thermohaline structure of the southwestern tropical Atlantic (SWTA), a key region for diagnosing variation of the Atlantic Meridional Overturning Circulation, has prime impact on global climate. Characterising the thermohaline structure is typically based on the application of classical statistical methods on vertical profiles. Such approach has important limitations since classical methods do not explicitly contemplate the vertical nature of the profiles. Functional Data Analysis (FDA) is a new alternative to solve such drawbacks. Here, we apply an FDA approach to characterise the 3D canonical thermohaline structure of the SWTA in austral spring and fall. Our results reveal a clear spatial pattern with the presence of three areas with significantly different thermohaline structure. Area 1, mostly located along the continental slope, reflects the western boundary current system, with low static stability and high frequency of occurrence of barrier layer (BL). Conversely, Area 2, located along the Fernando de Noronha chain, presents strong static stability with a well-marked thermocline. This area, under the influence of the eastern Atlantic, is characterised by a low BL frequency, which is seasonally modulated by the latitudinal oscillation of the Intertropical Convergence Zone, controlling the regime of precipitation. In turn, Area 3 behaves as a transition zone between A1 and A2 with the presence of the water core of maximum salinity in subsurface, and therefore presence of strong-moderate BL. Beyond this study, FDA approach emerges as a powerful way to describe, characterise, classify and compare ocean patterns and
\end{abstract}


processes. It can be applied to in situ data but could also be used to deeply and comprehensively explore ocean model output.

\section{Highlights}

- The thermohaline structure drives most near surface oceanic processes. A functional data analysis approach is used to characterise in 3D the thermohaline structure of the southwestern tropical Atlantic in spring and fall. We reveal a clear spatial pattern with the presence of three areas with significantly different thermohaline structure. The picture provided can serve as a reference for diagnosing future variation in the Atlantic Meridional Overturning Circulation.

Keywords : Thermocline, barrier layer, mixed layer, western boundary current, ocean stratification, North Brazilian Undercurrent system 


\section{Introduction}

An important and prevalent feature of the thermohaline structure of the upper ocean (here defined as the ocean region from the surface to $300 \mathrm{~m}$ depth) is the mixed layer (ML) occupying the first meters of the water column, in which temperature and salinity are vertically homogenous (Brainerd and Gregg, 1995). The thickness of the ML (Mixed Layer Depth - MLD) and the underlying discontinuity layers vary at different spatiotemporal scales (Grados et al., 2016; Kara, 2003). They are indeed controlled by surface forcing (heat exchange, wind-driving turbulent mixing, evaporation - precipitation budget, river inputs), Ekman pumping, advection of upwelled waters and internal waves (Halpern, 2002; Ker et al., 2016; Liu, 1993; Sprintall and Cronin, 2010).

Dynamical interactions between the oceanic ML and the thermocline/pycnocline drive most near surface oceanic motions (Chen et al., 1994; Rippert et al., 2015). In addition to ocean-atmosphere interaction, the storage of several gases (e.g. carbon dioxide and methane) and heat content are influenced by the variations in MLD (de Boyer Montégut et al., 2004; Kraus and Businger, 1994). Changes in MLD and thermocline thickness also affect the primary productivity (Jang et al., 2011; Sverdrup, 1953) by altering nutrients availability in the photic layer (Carranza et al., 2018; Madhupratap et al., 1981). Furthermore, deformations of the thermocline/pycnocline drive the seascape biological structure from zooplankton to top predators (Bertrand et al., 2014).

In some oceanic areas, the upper limit of the halocline is shallower than that of the thermocline, generating a Barrier Layer (BL) (Lukas and Lindstrom, 1991; Sprintall and Tomczak, 1992). The BL exerts an important influence on ML dynamics and, in particular, the interplay between kinetic and potential energy processes. This may affect the ocean heat budget (Pailler et al., 1999; Swenson and Hansen, 1999) through the heat fluxes with the atmosphere impacting meteorological conditions and rainfall regimes, with, for example, the generation of heavy precipitations (Balaguru et al., 2012; Hounsou-gbo et al., 2015). The BL also inhibits the transport of nutrients from deep water into the ML, which may results in nutrients depleted surface water (Williams and Grottoli, 2010).

The thermohaline circulation and associated inter-hemispheric transports of mass, heat, and salt in the southwestern tropical Atlantic (SWTA) has prime impact on global climate (Bourlès et al., 1999). The western boundary current system off Brazil is indeed a key region for diagnosing variations of the Atlantic Meridional Overturning Circulation (AMOC) by the southern wind-driven subtropical-tropical cell (STC). The STC is a shallow meridional overturning circulation transporting water subducted in the subtropics during the winter season to the tropics, where it is upwelled to the surface (Hummels et al., 2015; Zhang et al., 2003). It is an area through which oceanic signals on various timescales, from intra-seasonal to decadal scales pass (Dengler et al., 2004; Stramma and England, 1999). In this region, the intrusion of subtropical underwater (SUW) advected by the southern branch of the South Equatorial Current (sSEC) and then by North Brazilian Undercurrent (NBUC) (Bourles et al., 1999; Rodrigues et al., 2007; Silva et al., 2009; Stramma and Schott, 1999), is pointed out as a major process contributing to seasonal BL variability (Araujo et al., 2011).

The characterization of the thermohaline structure of an ocean region, as the SWTA, is typically based on vertical profiles measurements, where data is as discrete set of observations of temperature and salinity 
sampled at varying depths. However, the use of classical statistical methods for comparing or clustering such datasets (e.g. Principal Component Analysis (PCA) and Analysis of variance (ANOVA)) have important limitations. Indeed, classical methods do not explicitly contemplate the vertical nature of the profiles. For example, in a PCA matrix, vertical profiles depths are ordered in columns but PCA is invariant under permutation of columns in the data matrix. Functional Data Analysis (FDA) are a new alternative to solve this and other problems such as the use of diverse and heterogeneous datasets (Nerini et al., 2010; Pauthenet et al., 2019, 2017; Reyes et al., 2015).

FDA accounts for the functional nature of the data i.e. observed data are considered as a function rather than a vector of multiple measurements (Bayle et al., 2015; Pauthenet et al., 2017). Besides that, the extension of kriging techniques to the functional setting meets the need of interpolating complex data collected in a limited number of spatial locations and thus improve spatial inference (Menafoglio et al., 2013). If the functional nature of a functional dataset is ignored, results typically are sub-optimal as valuable information related to the functional nature of a dataset is not properly utilised (Hadjipantelis and Müller, 2018; Nerini et al., 2010).

Here, we propose to use functional statistics methods to characterise the 3D thermohaline structure of the SWTA in austral spring and fall. For that purpose, we used temperature and salinity profiles from two multidisciplinary surveys performed in northeast Brazil in spring 2015 and fall 2017. To construct a canonical picture of the spring and fall conditions we also used available profiles achieved in the SWTA in the same seasons in other years. Merging these databases was possible since the results of functional ANOVA did not reveal significant difference among datasets. From this, we provide a synoptic view of seasonal states of the thermohaline structure in the SWTA and reveal the presence of two different areas and one transition region, evidencing the variety of ocean-atmosphere processes in play in the region.

\section{Material and Methods}

\subsection{Data}

Conductivity, Temperature, Depth (CTD) hydrographic profiles were acquired using a CTD Seabird SBE911+ during the two multidisciplinary surveys Acoustic along the BRAzilian CoaSt (ABRACOS). The surveys were performed in northeast Brazil (Fig. 1, triangles) onboard the French R/V Antea in September and October 2015 (austral spring; ABRACOS1; Bertrand, 2015) and in April and May 2017 (austral fall; ABRACOS2; Bertrand, 2017).

To provide a more comprehensive view of the thermohaline structure in the SWTA in spring and fall, we also considered the use of ancillary vertical CTD profiles or profiling floats data from: (i) the World Ocean Atlas 2013 (https://www.nodc.noaa.gov/OC5/WOD13/); (ii) the REVIZEE program (Araujo et al. 2019); and (iii) the PANGEA Data Publisher for Earth \& Environmental Science (https://www.pangaea.de/). These ancillary data were selected considering the months of the ABRACOS surveys and the SWTA area $\left(3^{\circ}-10^{\circ} \mathrm{S} / 30^{\circ}-36^{\circ} \mathrm{W}\right)$, whatever the year. A total of 182 and 176 hydrographic profiles were considered for the periods of spring (Sep. - Oct.) and fall (Apr. - May), respectively (Table 1, Fig. 1). To describe the upper ocean thermohaline structure, ABRACOS and ancillary profiles were considered from the surface to $300 \mathrm{~m}$ depth. 
To investigate the atmospheric forcing, we analysed monthly average freshwater budget (evaporation minus precipitation - E-P) and near surface wind speed. For that, we used product composites of the Hamburg Ocean Atmosphere Parameters and Fluxes (HOAPS - v.4) with a regular $0.5^{\circ}$ x $0.5^{\circ}$ from 1988 to 2014. All variables were derived from recalibrated and intercalibrated measurements from SSM/I and SSMIS passive microwave radiometers compiled by the EUMETSAT's Satellite Application Facility on Climate Monitoring (CM SAF) (Andersson et al., 2017).

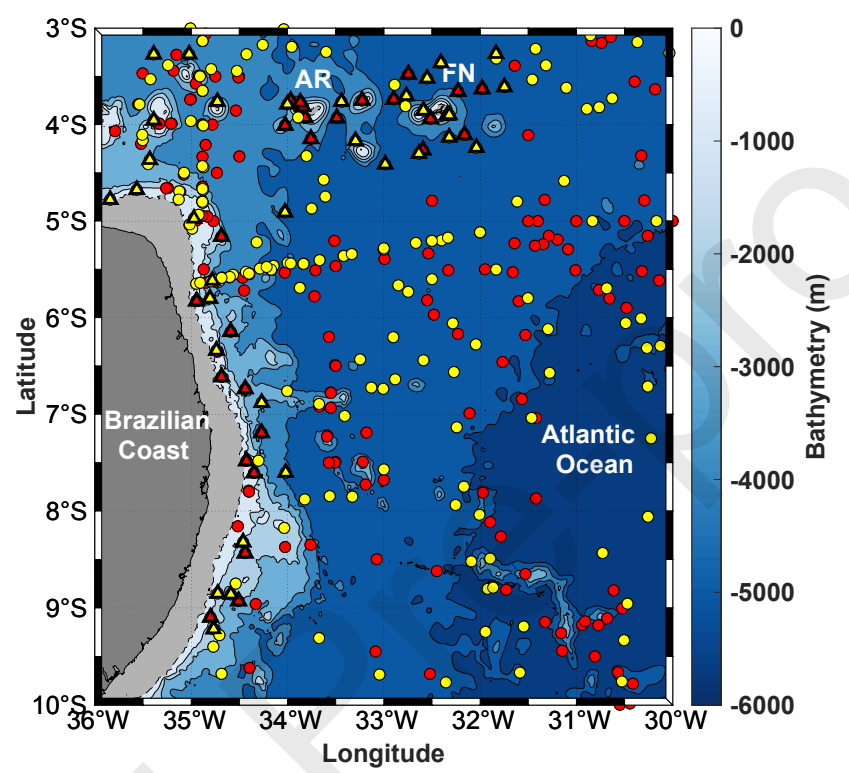

Figure 1. Study area in the southwestern tropical Atlantic (SWTA). Triangles: ABRACOS data; Circles: WOA 2013, REVIZEE and PANGEA datasets. Red symbols: spring data; Yellow symbols: fall data. The continental shelf is represented in light grey; the dashed line represents the shelf break (60 m isobath); other bathymetric contours (solid lines) are by $1000 \mathrm{~m}$ intervals. RA: Rocas Atol; FN: Fernando de Noronha archipelago.

Table 1. Databases in use.

\begin{tabular}{|c|c|c|c|c|}
\hline \multirow[t]{2}{*}{ Data } & \multirow{2}{*}{$\begin{array}{l}\text { Number } \\
\text { of profiles }\end{array}$} & \multicolumn{2}{|c|}{ Year of data acquisition } & \multirow{2}{*}{$\begin{array}{l}\text { Coverage area } \\
\text { Lat - Long }\end{array}$} \\
\hline & & Spring & Fall & \\
\hline ABRACOS & 62 & 2015 & 2017 & $\begin{array}{c}3.26^{\circ} \mathrm{S}-9.21^{\circ} \mathrm{S} \\
36.38^{\circ} \mathrm{W}-31.97^{\circ} \mathrm{W}\end{array}$ \\
\hline WOA & 237 & $1990,1992,1993,1995$ & $\begin{array}{l}1983,1984,1993 \\
1994,1995,2003 \\
2010,2017,2018\end{array}$ & $\begin{array}{c}3.00^{\circ} \mathrm{S}-9.99^{\circ} \mathrm{S} \\
31.5^{\circ} \mathrm{W}-35.88^{\circ} \mathrm{W}\end{array}$ \\
\hline REVIZEE & 39 & 1995,2000 & 1997,1999 & $\begin{array}{c}3.39^{\circ} \mathrm{S}-9.67^{\circ} \mathrm{S} \\
31.33^{\circ} \mathrm{W}-35.01^{\circ} \mathrm{W}\end{array}$ \\
\hline PANGEA & 80 & 2015,2016 & $2000,2003,2014$ & $\begin{array}{c}3.00^{\circ} \mathrm{S}-5.63^{\circ} \mathrm{S} \\
31.5^{\circ} \mathrm{W}-35.10^{\circ} \mathrm{W}\end{array}$ \\
\hline
\end{tabular}




\subsection{Defining the thermohaline structure}

To describe the thermohaline structure, we defined a series of parameters or limits (Fig. 2): the MLD, the BLT, the upper and lower limits of the thermocline and the pycnocline. There is no consensus for such definitions that vary according to the thermohaline structure of the studied area (Araujo et al., 2011; de Boyer Montégut et al., 2004; Holte and Talley, 2009; Ker et al., 2016, 2015). Here we defined these limits considering the specificity of the vertical profiles in the SWTA (Fig. 2).

We determined the MLD using the criteria from Sprintall and Tomczak (1992), i.e. the depth at which density $(\sigma)$ is equal to the density at the reference depth $\left(z_{0}=10 \mathrm{~m}\right.$ depth), plus an increment $\left(\frac{\partial_{\theta}}{\partial_{\theta}} \Delta_{\theta}\right)$, which is equivalent to temperature steps $-\Delta_{\theta}=0.5^{\circ} \mathrm{C}$ and its equivalent in density change at constant salinity $\left(s_{z_{0}}\right)$. Moreover, previous studies in the western tropical Atlantic also used the $0.5^{\circ} \mathrm{C}$ criterion for the isothermal layer and its equivalent in density change (Araujo et al., 2011; Silva et al., 2005; Tanguy et al., 2010), whose are found to be the most adaptable due to their robustness.

$$
M L D=z\left(\sigma_{\theta_{Z_{0}}}+\frac{\partial_{\sigma_{\theta}}}{\partial_{\theta}} \Delta_{\theta}\right)
$$

To define the Upper Thermocline Depth (UTD), we compared three criteria: the depth of the maximum temperature gradient, the isothermal layer with $0.5^{\circ} \mathrm{C}$ as a threshold (Tangy et al., 2010), and $\partial_{\theta} / \partial_{z}=$ $0.1^{\circ} \mathrm{C} / \mathrm{m}$ (Ker et al., 2016). The two last criteria reached similar results, while the maximum gradient method tends to overestimate the UTD. Following Ker et al. (2016) and checking by visual inspection, we used $\partial_{\theta} / \partial_{z}=0.1^{\circ} \mathrm{C} / \mathrm{m}$ to identify the UTD.

To determine the Lower Thermocline Depth (LTD), which also coincides with the Lower Pycnocline Depth (LPD) (Fig. 2), we used the Brunt Väisälä frequency $\left(N^{2}\right.$, the buoyancy frequency squared),

$$
N^{2}=-\frac{g \partial_{\sigma_{z}}}{\sigma_{0} \partial_{z}}
$$

where, $g$ is the acceleration of gravity and $\sigma_{0}$ is a reference density at $10 \mathrm{~m}$ (Kim and Miller, 2007; Liu et al., 2016). Specifically, we considered the lower thermocline/pycnocline depth to be the last depth below the UTD where $N^{2}$ is of up to four orders of magnitude $\left(N^{2} \geq 10^{-4}\right)$. This method was chosen based on evidence that in the thermocline/pycnocline that acts as a transition layer, the shear instabilities can produce higher buoyancy frequencies compared to the stable layers above and below it. In vertical profiles (Fig. 2), $N^{2}$ is close to zero (in the order of $1 \times 10^{-6}$ ) above the pycnocline; it increases continuously within the thermocline/pycnocline layer (Maes and O'Kane, 2014) reaching values greater than $1 \times 10^{-3}$. Below the pycnocline/thermocline, $N^{2}$ decreases to reach values similar to those of the mixed layer (Johnston and Rudnick, 2009; Maes and O'Kane, 2014; Sun et al., 2013). In such an environment, the criterion $N^{2} \geq$ $10^{-4}$ was well fitted to define the base of the thermocline. 
The thermocline thickness (TT) was calculated by the difference between the upper and lower limits of the thermocline (TT = LTD/LPD - UTD). Finally, the Barrier layer thickness (BLT) was calculated as the difference between the MLD and the UTD (BLT = MLD - UTD) (Lukas and Lindstrom, 1991).

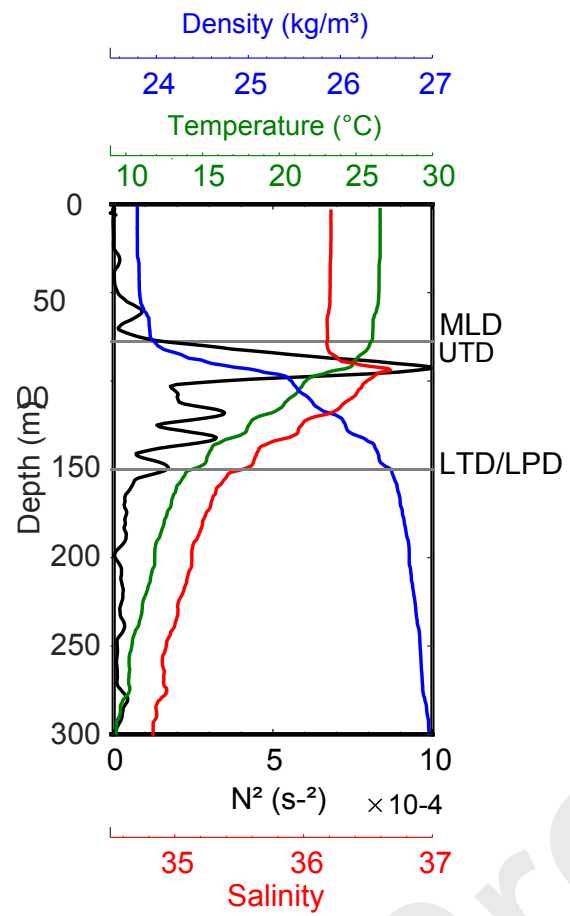

\begin{tabular}{llll}
\multicolumn{4}{c}{ Density $\left(\mathrm{kg} / \mathrm{m}^{3}\right)$} \\
\hline 24 & 25 & 26 & 27 \\
\multicolumn{3}{c}{ Temperature $\left({ }^{\circ} \mathrm{C}\right)$} &
\end{tabular}
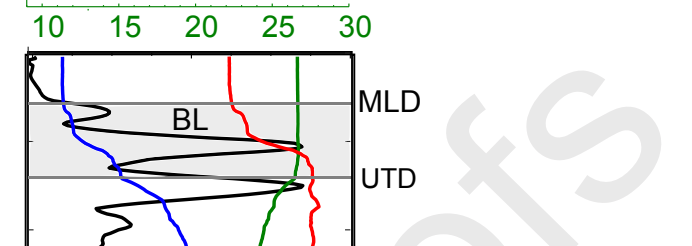

Figure 2. Examples of CTD profiles from ABRACOS 1 (spring) with the representation of the thermohaline structure as defined from the temperature, salinity, density and squared buoyancy frequency $\left(N^{2}\right)$. MLD: mixed layer depth; UTD: upper thermocline depth; LTD/LPD: lower thermocline/pycnocline depth; BL: barrier layer (present in the right profile only).

\subsection{Functional Data Analysis (FDA)}

FDA is a branch of statistic that provides tools for describing and modelling sets of functions (or curves) rather than vectors of discrete values (Ramsay, 2006). The guiding idea of this approach is to describe data as parameterized functions, and to use these parameters for clustering, comparing or interpolating functions. In particular, classical statistical tools can be adapted to functional data such as functional principal component analysis (fPCA) to summarize and characterize significant variation in finite dimension among a sample curves (Dabo-Niang and Ferraty, 2008; Ramsay, 2006). Functional analysis of variance (fANOVA) uses all the information of each mean functional curve to test the possible differences in the datasets, based on the shape and temporal (along the depth) variability of the curves (Cuevas et al., 2004; Ramsay, 2006).

Here, each temperature and salinity profile were treated as a separate function (curve) in FDA and we used a variety of functional statistical methods to define and characterise the $3 \mathrm{D}$ thermohaline structure. A summary flowchart documenting the methodology sequence for the use of FDA is presented in Figure 
3 and described below. All analyses (i.e. fitting, clustering, and kriging) were done separately for salinity and temperature profiles.

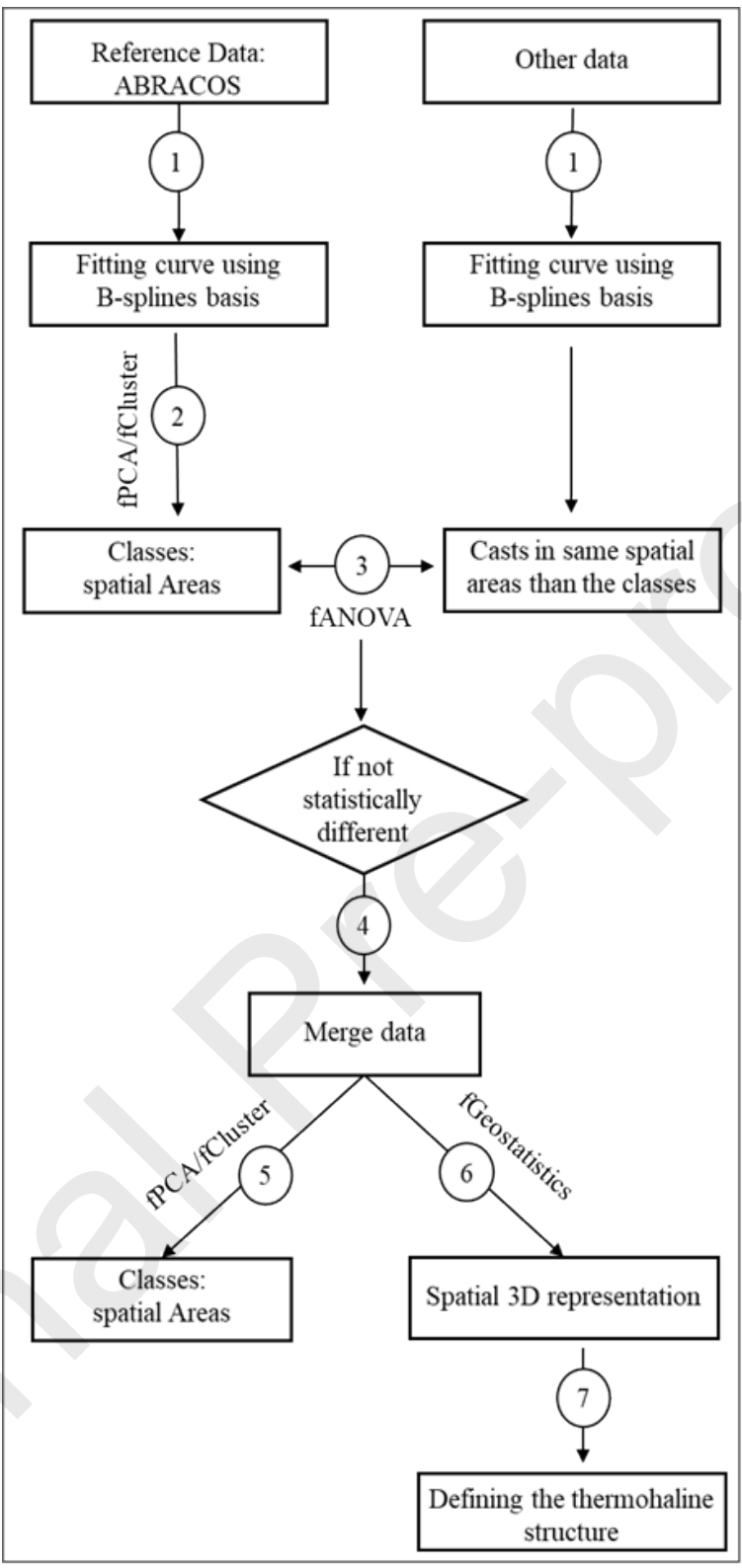

Figure 3. Summary flowchart documenting the methodology sequence for the Functional Data Analysis approach and definition of the themohaline structure. This framework has been followed for both temperature and salinity profiles, separately. 


\subsubsection{Fitting B-spline functions}

To apply FDA (Ramsay, 2006), the first step consists in transforming the data into function (Fig. 3, step 1). To describe a vertical profile as a single entity, the existence of a smooth function giving rise to the observed data is assumed. It is expressed as:

$$
y_{i}=x\left(z_{i}\right)+\epsilon_{i}
$$

where $\left(z_{i}, y_{i}\right), i=1, \ldots, N$ are the data, $z$ is depth and $y$ temperature or salinity, $\epsilon_{i}$ is a remainder that is expected to be as small as possible. The function $x(z)$ is in the form of a linear combination of each basis function $\phi_{k}(z), k=1, \ldots, K$ such that:

$$
x(z)=\sum_{k=1}^{K} c_{k} \phi_{k}(z)
$$

where $c_{k}$ are coefficients estimated by penalized regression using pointwise data $\left(z_{1}, y_{1}\right), \ldots,\left(z_{N}, y_{N}\right)$ (Ramsay, 2006).

Spline functions to smooth data are the most common choice of approximation system for nonperiodic functional data. It combines fast computation of polynomials approach with substantially greater flexibility. Therefore, a B-spline basis of degree 3 (Boor, 2001) has been used. Then, to reduce the impact of noise in the measurement when interpolating, a solution is to determine a roughness parameter $\lambda$, such that parameters of $x_{i}$ will be estimated by minimizing the penalized squared difference (error):

$$
P S E=\sum_{k=i}^{n}\left(y_{i}-x_{i}(z)\right)^{2}+\lambda \int\left[D^{2} x(z)\right]^{2} d z \quad \text { (Eq. 5) }
$$

where the notation $D^{2} x(z)$ refers to the second derivative of fit (Ramsay, 2006).

A good choice of the dimension of the basis $K$, and of the penalized parameter $\lambda$ of the basis consists in finding the right balance between smoothing and interpolating the data. The higher the number of $K$ functions, the more complexity is preserved. We first defined an interval of potential $K$, by making a sensitivity test by carrying out smoothing for temperature and salinity according to different $K$. Then, we performed a Generalized Cross-Validation (GCV) to estimate the optimal basis $K$ and $\lambda$, within this interval, using the R packages " $f d a "$ and " $f d a$. usc" (Febrero-Bande and Fuente, 2012).

\subsubsection{Comparing ABRACOS and ancillary datasets}

Once the hydrographic profiles have been described with a relevant functional basis, the next step was to compare the ABRACOS and ancillary data. Indeed, we aimed at determining if these datasets could be merged to be representative of spring and fall canonical states in the study region. This question has been addressed in two steps (Fig. 3, steps 2 and 3) using the most recent ABRACOS observations as a reference. 
First (Fig. 3, step 2), we characterised the ABRACOS profiles by applying PPCA and a functional hierarchical clustering (fCluster), achieved on the coefficients of the fPCA decomposition (Febrero-Bande and Fuente, 2012). Reproducing the aim of PCA, the idea of the PPCA is to summarize multivariate dataset with principal component seen as a linear combination of the variables (the same apply for fCluster). In comparison, the method is adapted to deal with function rather than vector and the principal components corresponds to dominant modes of variation of functional data (Shang, 2014). PPCA allowed identifying the main patterns of variation of the vertical profiles while fCluster were used to statistically define homogeneous groups of profiles. These groups were then plotted spatially to determine if they correspond to specific areas.

Second (Fig. 3, step 3), once homogeneous areas were defined from ABRACOS profiles, we applied a fANOVA to compare ABRACOS and ancillary profiles present in each area. fANOVA is based on the so-called one-way analysis of variance for univariate functional data using L2-norm-based parametric bootstrap test for homoscedastic samples (Cuevas et al., 2004). This procedure considers $l$ groups of independent random functions such that each function of the group $A$ is assumed to be a stochastic process with mean function $\mu_{k}(t), A=1 \ldots l$ and tests the null hypothesis:

$$
H_{0}: \mu_{1}(t)=\ldots=\mu_{l}(t) .
$$

This analysis has been performed with the use of "fdanova" R package (Febrero-Bande and Fuente, 2012).

\subsubsection{Data characterisation and 3D spatial interpolation}

In case of no rejection of the null hypothesis (Fig. 3, step 4), profiles from the different datasets can be merged to build complete dataset representative of spring and fall canonical states. Then fPCA, fCluster and fANOVA can be applied on the complete merged dataset to characterise the profiles and their spatial variability (Fig. 3, step 5).

To interpolate temperature and salinity profiles in 3D (Fig. 3, step 6) we applied a functional geostatistical analysis (Giraldo et al., 2007). Geostatistics (or kriging methods) are well-known tools for model-based spatial interpolation, taking into account the spatial autocorrelation of an estimated set of variables (Matheron, 1963). The fundamental premise of kriging methods is that spatial data constitute a joint realization of spatially dependent random variables, collectively referred as a random function. Ordinary kriging refers to spatial prediction under the assumption of stationarity as specified by Cressie (1993) and Wackernagel (2003). More precisely, the random function is supposed stationary, meaning that the expectation of the random function is independent of the position. This framework has been generalized to be useful within the FDA context. Yet, because we are dealing with functions, the stumbling block remains in the estimation of a spatial covariance between curves.

The functional geostatistical analysis has been performed according to ordinary trace kriging method (Giraldo et al., 2011) in order to described the spatial autocorrelation structure of functional data. The method is implemented in "fdagstat" R package (https://github.com/ogru/fdagstat), and has involved the two following steps: (i) the analysis of spatial structure (i.e. through the calculation and fitting of a 
variogram); (ii) and the use of this structure for predicting functional data at unknown location. Spherical model has been used to fit the different variograms to temperature and salinity profiles

To evaluate the quality of the functional geostatistical models we performed cross-validation analyses. For that, we randomly removed $2 \%$ of the sampled curves (profiles) and performed the functional Kriging predictor for the remaining $98 \%$ curves to predict the removed curves. Observed profiles, fitted with 41 and $44 \mathrm{~B}$-spline basis $(K)$ to temperature and salinity, respectively, were compared with a Krigingpredicted curve for each site. This procedure was applied the number of times enough to cover all profiles sampled in situ. We used the Mean Square (MSD) differences i.e., the mean of the squared error between predicted and real transects (for all depth) to evaluate the quality of the prediction. Finally (Fig. 3, step 7), we applied the criteria defining the MLD, the BLT, the upper thermocline depth, and the lower thermocline/pycnocline depth to the interpolated fields of temperature and salinity, to obtain a comprehensive vision of the thermohaline structure in the SWTA. In each area and for each season, we also calculated the BL occurrence frequency (BLF, in \%) defined as the percentage of area with BLT higher than $5 \mathrm{~m}$ (Zeng and Wang, 2017).

\section{Results}

\subsection{Merging the datasets}

For both seasons, the fPCA and fCluster analysis of the ABRACOS thermohaline profiles revealed two significant areas (classes, the dendrograms are provided in the Supplementary Figure S1), in which profiles display similar shape (Fig. 4). The first area corresponds to the surrounding of the SWTA slope, hereafter referred to as A1. The second area hereafter referred as A2 encompasses the oceanic islands (Fernando de Noronha and Rocas Atoll) and seamounts (Fig. 4e, j). 

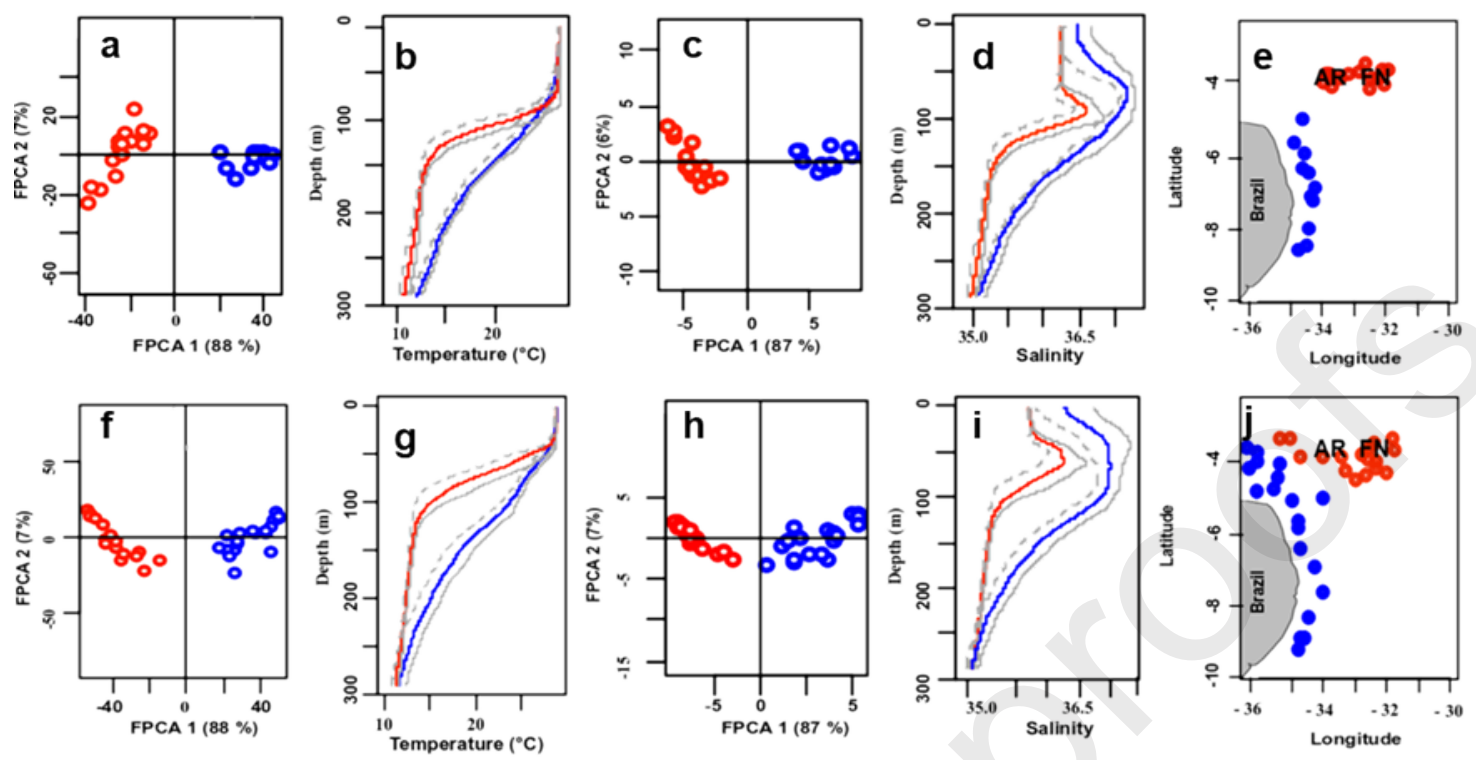

Figure 4. Scores of the first two PCAs components temperature in spring (a) and fall (f), and salinity in spring (c) and fall (h) from ABRACOS data only. The colour corresponds to the class defined by the functional clustering preformed on the data (blue: class A1; red: class A2). Mean temperature (b, g) and salinity (d, i) profiles for each class obtained from the in spring (b, d) and fall (f, i). Spatial distribution of the classes/area for spring (e) and fall (j). The grey dashed and full lines illustrate the variation over the mean profiles.

In each area and for each variable (temperature and salinity) and season (spring and fall), no significant differences (fANOVA, $\mathrm{p}>0.05$ ) were observed between the profiles from ABRACOS and other data (Fig. 5). fANOVA results verify that the data obtained during the ABRACOS surveys, are representative of a canonical state of spring and fall for SWTA. We thus merged all datasets in one complete dataset (from now the reference) of oceanic profiles per season (see Fig. 3, step 4). When performing the fPCA and fCluster analyses on the complete dataset, in addition to the A1 and A2, we identified a third thermohaline class, hereafter referred as A3, corresponding to the central offshore zone between A1 and A2 (Fig. 6). 

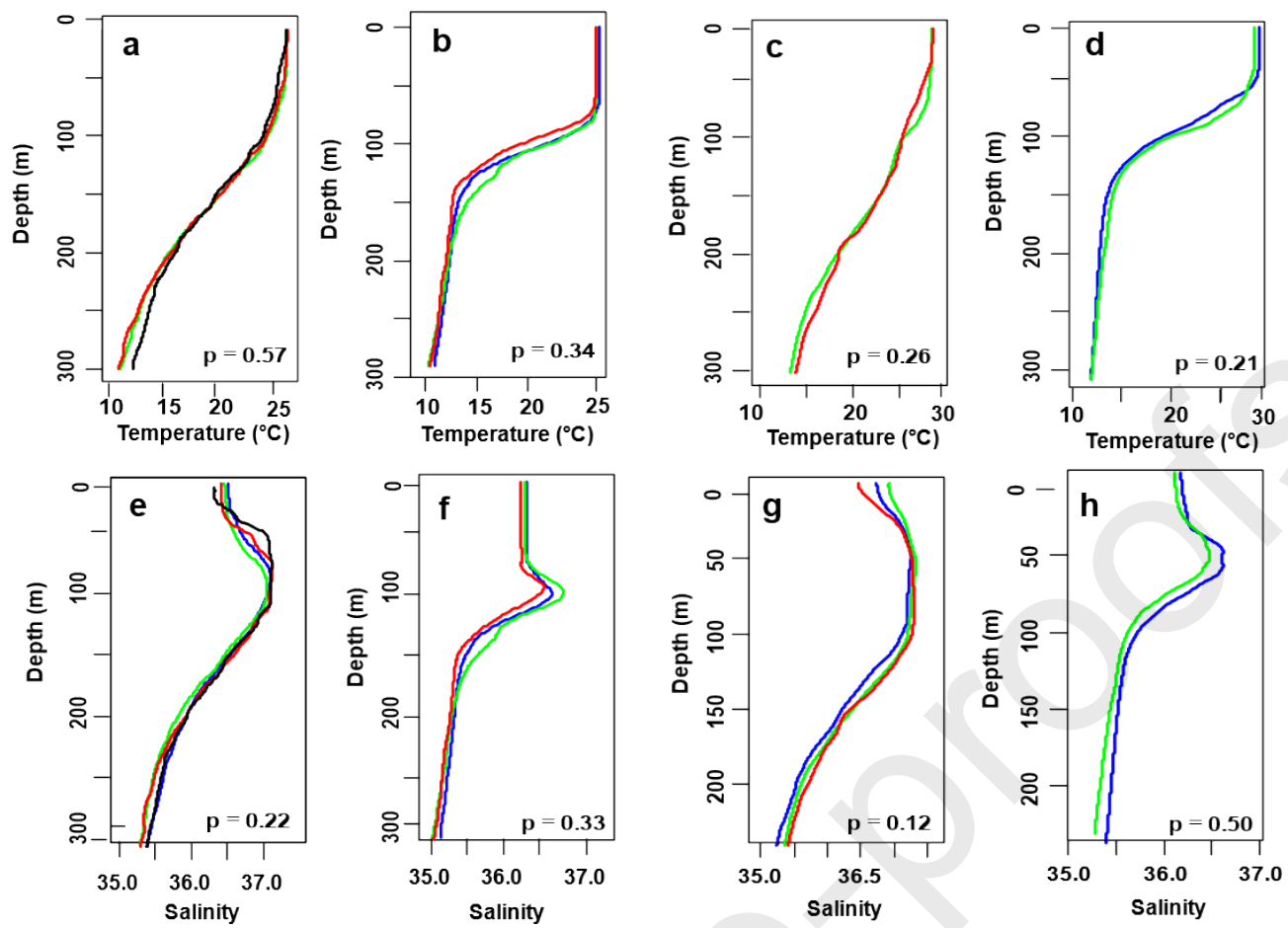

Figure 5. Functional ANOVA between the mean profiles from different databases by area: spring temperature in A1 (a); spring temperature in A2 (b); fall temperature in A1 (c); fall temperature in A2 (d); spring salinity in A1 (e); spring salinity in A2 (f); fall salinity in A1 (g); and fall salinity in A2 (h). Colours refer to data sources; blue: ABRACOS, red: WOA, green: PANGEA and black: REVIZEE.

\subsection{Typology of thermohaline patterns}

The application of the PPCA and fCluster on the complete dataset allowed dividing the study area into three significantly different areas during both seasons (Fig. 6, the dendrograms are provided in the Supplementary Figure S1). We observed the two classes of profiles already depicted using ABRACOS data only (A1 and A2 in Fig. 4) with A1 extending to the entire longitudinal extension $\left(35^{\circ} \mathrm{W}-30^{\circ} \mathrm{W}\right)$ south of $8^{\circ} \mathrm{S}$ at both seasons (Fig. 6b, d, f, h). In addition to A1 and A2, we identified a third class, A3, corresponding to the central offshore zone between A1 and A2 (Fig. 6). Note that some spatial overlap between profiles characterised in different area occurs, mainly in the transition zone between A2 and A3 (Fig. 6b, d, f, h). 

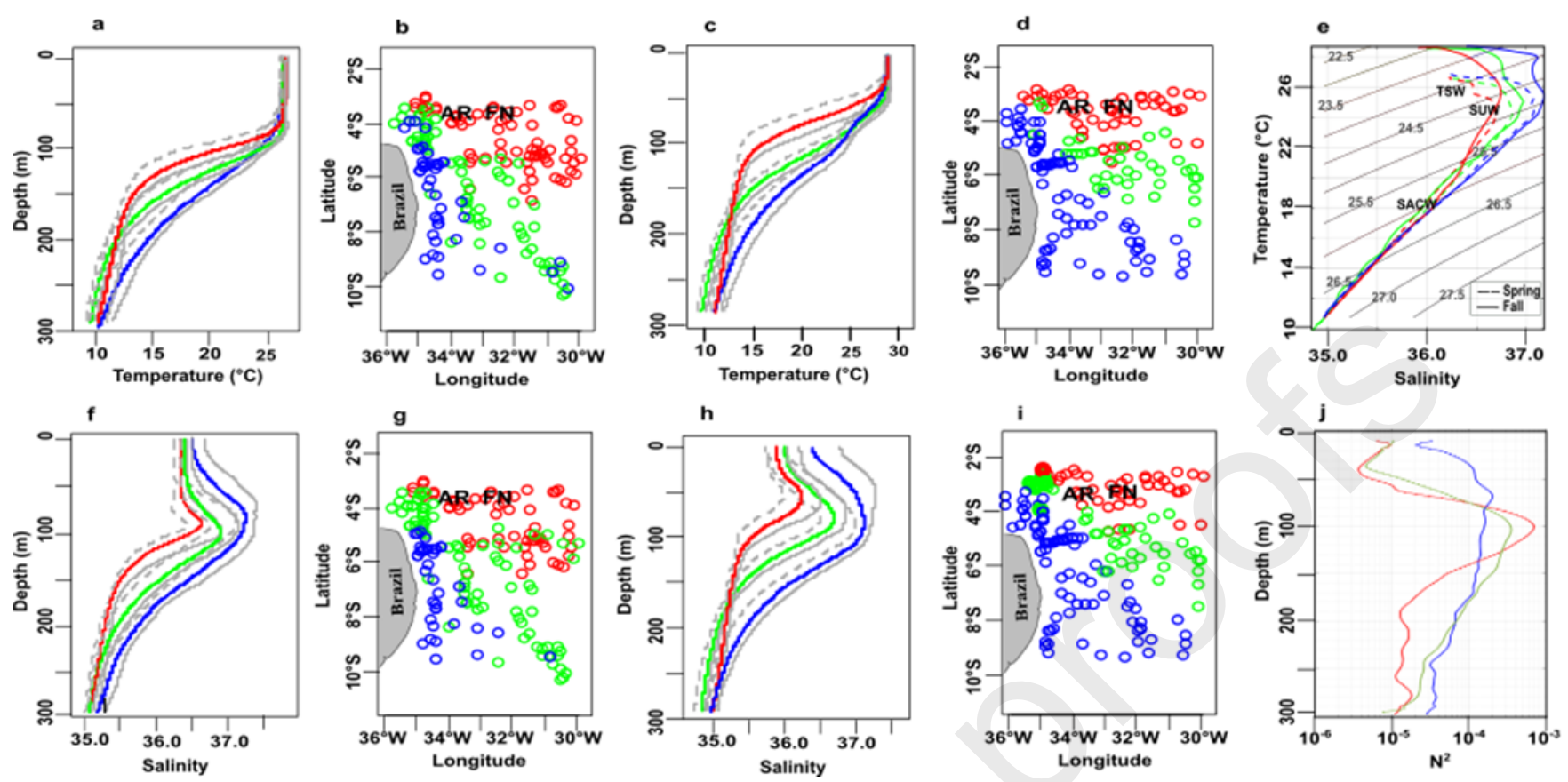

Figure 6. Mean vertical profiles of temperature $(a, c)$ and salinity $(f, h)$ of each class/area identified by functional PCA and clustering in spring $(a, f)$ and fall $(c, h)$. The grey solid and dashed lines illustrate the variation over the mean profiles. Spatial distribution of the classes/area for temperature (b, d) and salinity (g, i). (e) TS diagrams for each class, with spring represented by dashed lines and fall by solid lines. (j) Static stability (in terms of buoyancy frequency, $\mathrm{N}^{2}$ ). In all plots, the colours blue, red and green represent the areas 1, 2 and 3, respectively.

In $\mathrm{A} 1$, temperature profiles were characterised by a low stratification with a thermocline extending from $70 \mathrm{~m}$ to $172 \mathrm{~m}$ in spring (Fig. 6a) with a thermal difference of $7.7^{\circ} \mathrm{C}$, and from $58 \mathrm{~m}$ to $166 \mathrm{~m}$ in fall (Fig. 6c) with a temperature difference of $9.7^{\circ} \mathrm{C}$. Salinity profiles presented the saltiest waters with a peak of salinity reaching 37.1 at $98 \mathrm{~m}$ in spring (Fig. 6e), and 37.2 at $68 \mathrm{~m}$ in fall (Fig. $6 \mathrm{~g}$ ).

In A2, temperature profiles were characterized by a high stratification with a sharp thermocline extending from $86 \mathrm{~m}$ to $132 \mathrm{~m}$ in spring (Fig. 6a) with a thermal difference of $10.8^{\circ} \mathrm{C}$, and from $50 \mathrm{~m}$ to $100 \mathrm{~m}$ in fall (Fig. 6c) with a thermal difference of $12.3^{\circ} \mathrm{C}$. Salinity profiles presented the lowest salinity, with maximum values reaching 36.6 at $100 \mathrm{~m}$ in spring (Fig. 6e) and 36.4 at $72 \mathrm{~m}$ in fall (Fig. 6g).

In A3, temperature profiles were characterized by low stratification with a thermocline extending from $90 \mathrm{~m}$ to $160 \mathrm{~m}$ in spring (Fig. 6a) with a thermal difference of $10.7^{\circ} \mathrm{C}$ in, and from 64 to $158 \mathrm{~m}$ in fall (Fig. 6c) with a thermal difference of $9.9^{\circ} \mathrm{C}$. Salinity profiles presented intermediate salinity values with a maximum of 36.7 at $108 \mathrm{~m}$ in spring (Fig. 6e), and 36.8 at $92 \mathrm{~m}$ in fall (Fig. 6g).

To identify the water-masses present in each area for each season we used TS diagram (Fig. 6e). Surface Tropical South Water are warm surface water (Stramma and England, 1999) with $\sigma_{\theta}$ above 24.5 kg.m ${ }^{-3}$ (Gasparin et al., 2014; Urbano et al., 2008) observed in all three areas with seasonal changes mostly driven by the temperature. Below, in the upper part of the thermocline, lies the Subtropical Underwater 
(SUW) (Lambert and Sturges, 1977) formed by the excess of evaporation over precipitation in the subtropics and advected westward within the subtropical gyre (Bourlès et al., 1999). This water-mass, observed in all three areas, is characterised by its high salinity ( $>36.5$; Stramma and England, 1999). Finally, in subsurface, in the lower part and below the thermocline, the South Atlantic Central Water $\left(24.5<\sigma_{\theta}<27 \mathrm{~kg} . \mathrm{m}^{-3}\right.$, Stramma and England, 1999) dominates, whatever the season or area.

\subsection{D thermohaline patterns}

From functional geostatistics, we characterised the 3D temperature and salinity fields for the canonical state of spring and fall in the SWTA. Validation procedure (Fig. 7 for spring, see Supplementary Figure S2 for fall) shows that the ordinary trace-kriging provides an acceptable estimation of temperature and salinity profiles at any locations of the sampled domain, independent of the areas (A1, A2 and A3). Examples of original profiles for randomly selected sites and their predicted equivalents are shown, for each profile the root mean square of the differences between predicted and observed values (applied along the profile) was calculated to estimate the accuracy. The boxplots of the MSD (Fig. 7) and associated global statistics show that in most cases the goodness of fit was good with similar predicted and observed smoothed curves. However, in some extreme cases the goodness of fit was not optimal (e.g. profiles 2 and 4 in Fig. 7) but the shape was preserved.
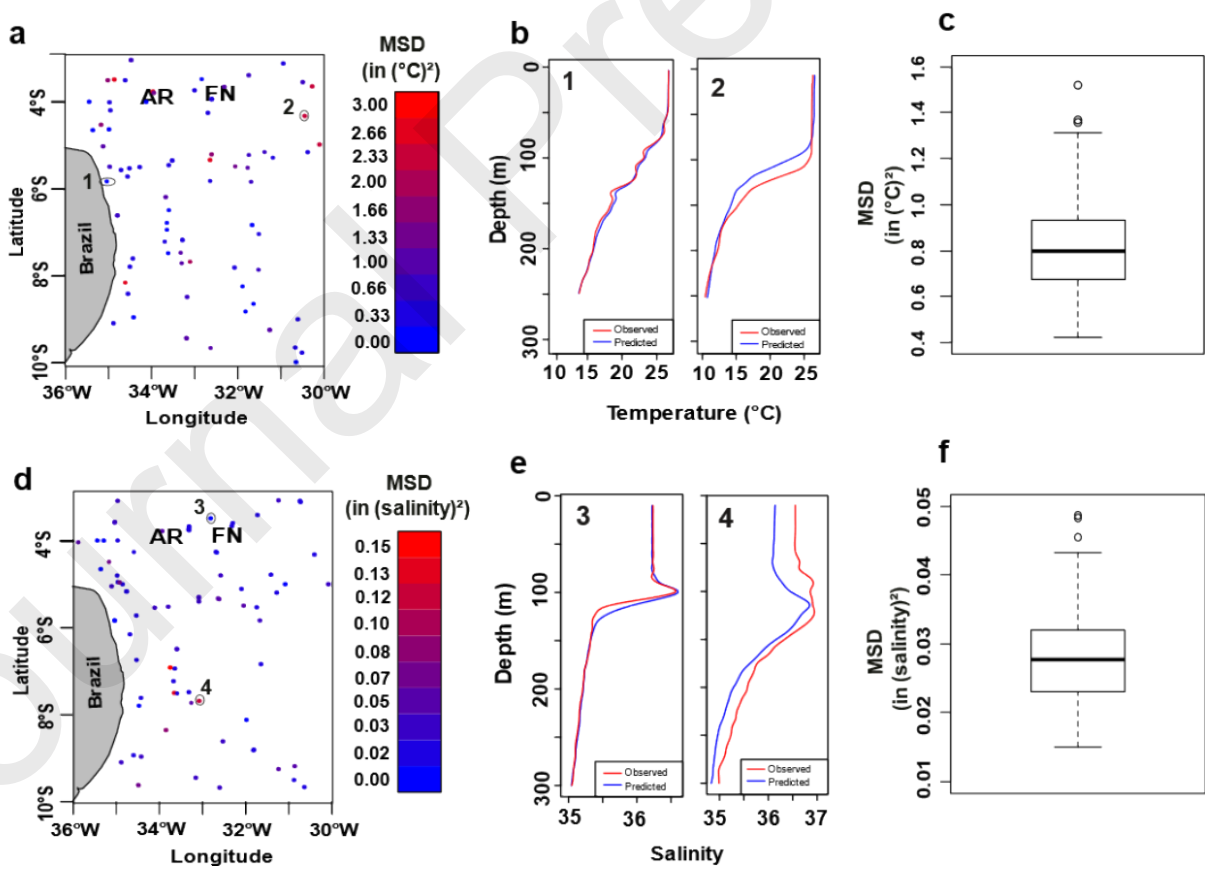

Figure 7. Validation for Functional Ordinary Kriging of temperature $\left({ }^{\circ} \mathrm{C}\right)(\mathrm{a}, \mathrm{b}, \mathrm{c})$ and salinity $(\mathrm{d}$, e, f) in spring using the Mean Square Difference (MSD). Maps of the distribution of the MSD for all stations for temperature (a) and salinity (d). Examples or good (1 and 3) and worst (2 and 4) predictions for temperature (b) and salinity (e). The corresponding profiles are circled in (a) and (d). The red solid lines correspond to the observations and the blue 
solid line to the predictions. The boxplots of the MSD for temperature (c) and salinity (f) are presented to evaluate the global performance of the estimators.

\subsubsection{Temperature and salinity $3 D$ fields}

3D temperature and salinity interpolated fields are available in supplementary material (supplementary movies SM1, 2, 3 and 4.) and are presented in 2D at three depths (Figs. 8 and 9). These depths were chosen to represent the patterns in surface $(10 \mathrm{~m})$, within $(110 \mathrm{~m})$ and below $(200 \mathrm{~m})$ the thermocline/pycnocline. In spring, the Sea Surface Temperature (SST, temperature at $10 \mathrm{~m}$ depth) (Fig. 8a) was nearly homogeneous (median $\sim 26.6^{\circ} \mathrm{C}$ ) over the whole study area, while it was about $2^{\circ} \mathrm{C}$ higher in fall (Fig. $8 \mathrm{~b}$ ), ranging from $28.0^{\circ} \mathrm{C}$ to $29.2^{\circ} \mathrm{C}$ (median $\sim 28.6^{\circ} \mathrm{C}$ ), with highest values in the central part of $\mathrm{A} 3$. At 110 $\mathrm{m}$, a clear temperature gradient was observed during both seasons (Fig. 8c, d) with lower temperature north of $\sim 6^{\circ} \mathrm{S}$ (A2) than further south (A1 and A3). At $200 \mathrm{~m}$ (Fig. 8e, f), we observed strong spatial patterns with a core of warm waters over the continental slope (A1).

In spring, the surface salinity (Fig. 9a) ranged between 36.1 and 36.6, with the highest values along the continental slope (A1). In fall, the surface salinity (Fig. 9b) gradient was stronger with the highest values (up to 37.4) also near the continental slope (A1). The lowest salinities were observed offshore between $3^{\circ} \mathrm{S}-6^{\circ} \mathrm{S}(\mathrm{A} 2, \mathrm{~A} 3)$. At $110 \mathrm{~m}$, the salinity gradient reinforced (Fig. 9c, d) with lower salinity 36.0 (35.4) in spring (fall) north of $7^{\circ} \mathrm{S}(\mathrm{A} 2, \mathrm{~A} 3)$ than along the continental slope and in southern region (A1) where salinity reached 37.1 (37.3) in spring (fall). At $200 \mathrm{~m}$, the salinity was lower than in upper layers, but the gradient was still observed (Fig. 9e, f) with higher salinity in A1 than A2 and A3, where the lowest salinity was observed. 

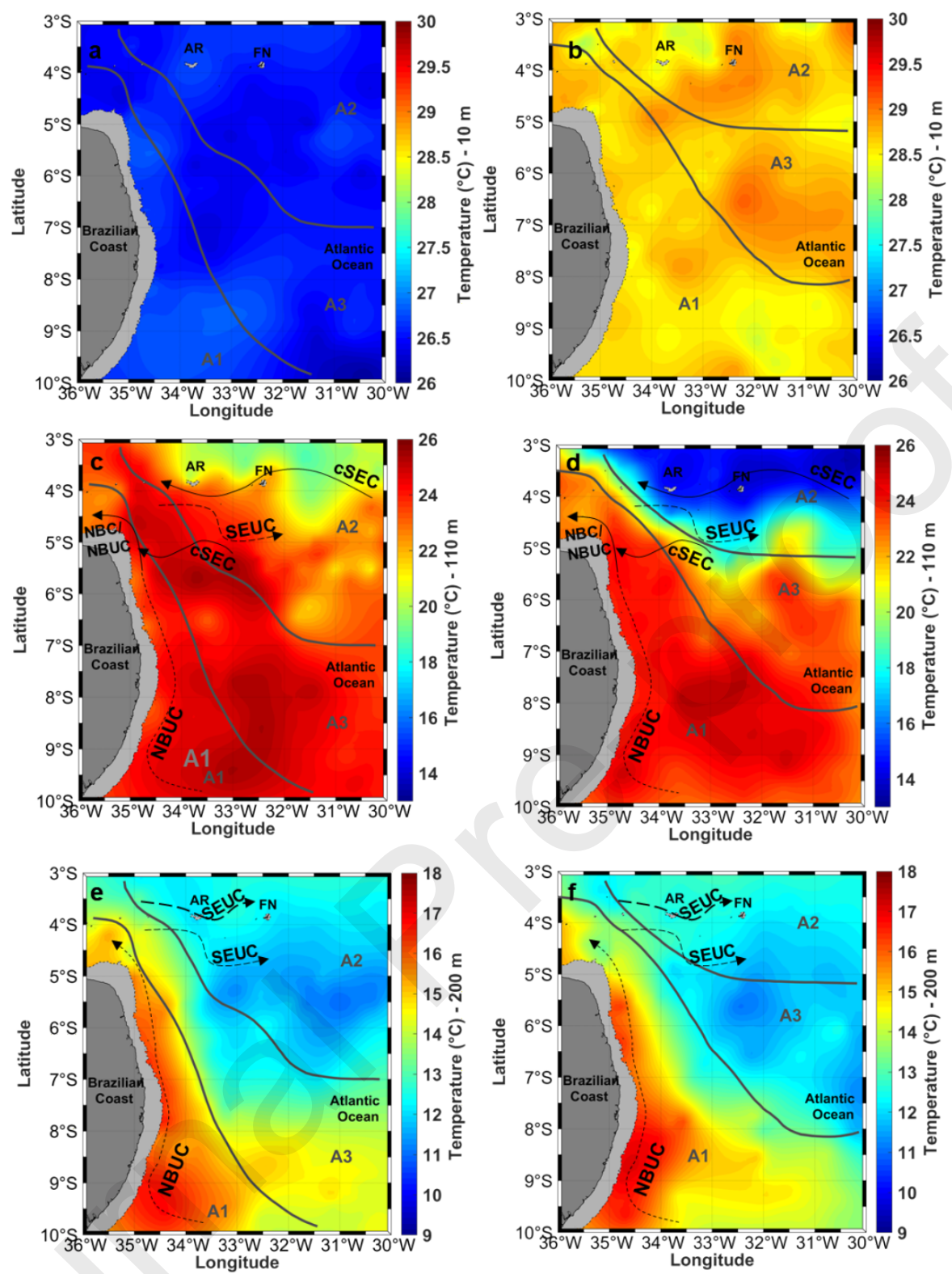

Figure 8. Sea temperature in spring (a, c, e) and fall (b, d, f) at $10 \mathrm{~m} \mathrm{(a,b),110} \mathrm{m} \mathrm{(c,} \mathrm{d)} \mathrm{and} 200 \mathrm{~m}(\mathrm{e}, \mathrm{f})$ in the southwestern tropical Atlantic. Grey solid lines delimit areas A1, A2 and A3 defined in section 3.2. The continental shelf limited by the isobaths of $60 \mathrm{~m}$ is represented by light grey. RA: Rocas Atoll; FN: Fernando de Noronha archipelago. The main currents are represented. cSEC: central branch of the South Equatorial Current. SEUC: South Equatorial Undercurrent. NBUC. North Brazilian Undercurrent; NBC: North Brazilian Current. Note that the temperature scale varies according to the depths $10 \mathrm{~m}, 110 \mathrm{~m}$ and $200 \mathrm{~m}$. 

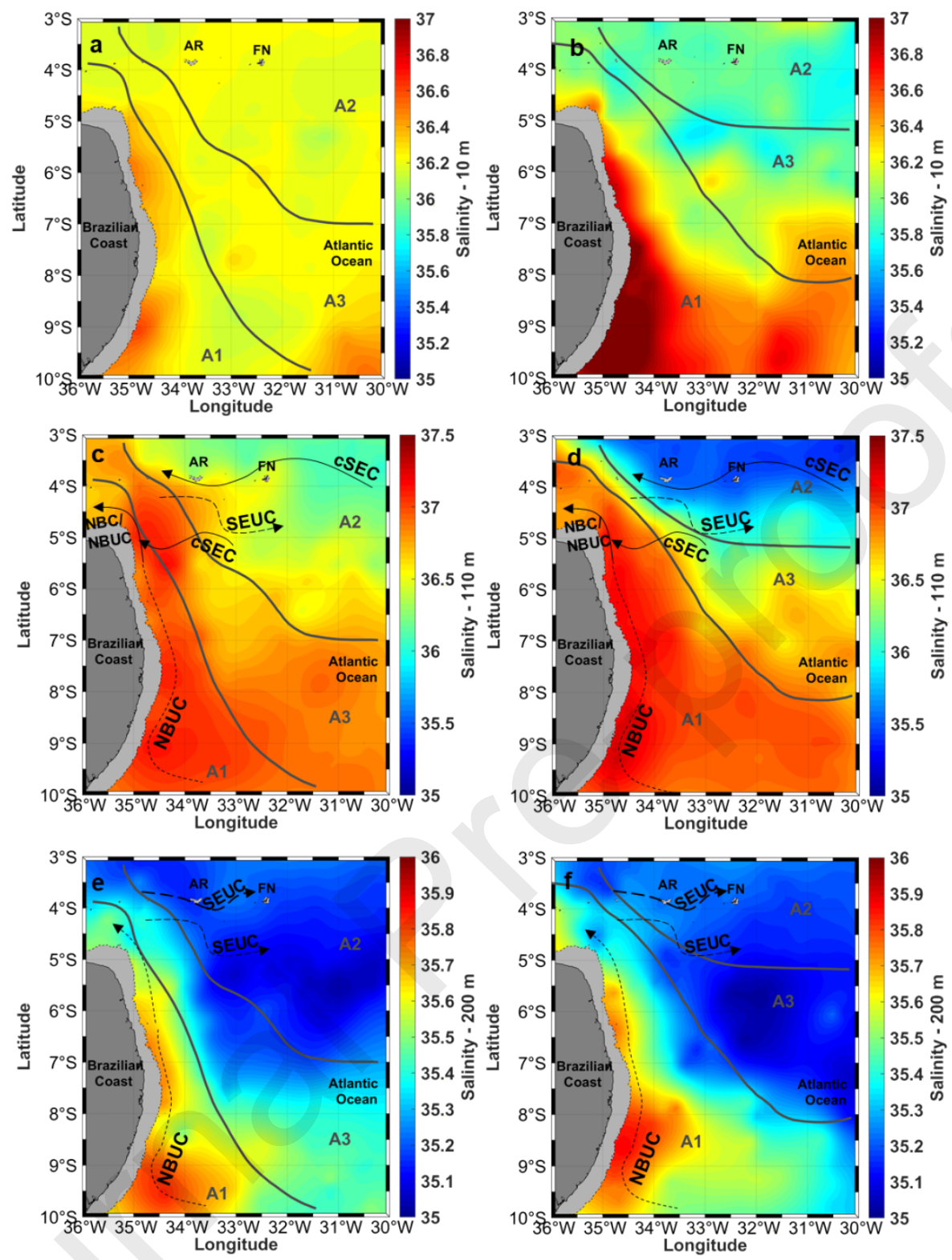

Figure 9. Sea salinity in spring (a, c, e) and fall (b, d, f) at $10 \mathrm{~m} \mathrm{(a,b),110} \mathrm{m} \mathrm{(c,} \mathrm{d)} \mathrm{and} 200 \mathrm{~m}(\mathrm{e}, \mathrm{f})$ in the southwestern tropical Atlantic. Grey solid lines delimit areas A1, A2 and A3 defined in section 3.2. The continental shelf limited by the isobaths of $60 \mathrm{~m}$ is represented by light grey. RA: Rocas Atoll; FN: Fernando de Noronha archipelago. The main currents are represented. cSEC: central branch of the South Equatorial Current. SEUC: South Equatorial Undercurrent. NBUC. North Brazilian Undercurrent; NBC: North Brazilian Current. Note that the temperature scale varies according to the depths $10 \mathrm{~m}, 110 \mathrm{~m}$ and $200 \mathrm{~m}$. 


\subsubsection{Thermohaline structure}

The MLD, the BLT, the upper thermocline depth and the lower thermocline/pycnocline depth were estimated from the interpolated temperature and salinity fields for each season (Fig. 10, see Table 2 for synthetic description). To verify the robustness of these estimates we also performed these calculations using the B-spline fitted original profiles for each Area. This comparison (Table 2) reveals very small differences. To better illustrate the spatial patterns, we also plotted the thermohaline structure over vertical sections along the slope, cross-shore (at $5.5^{\circ} \mathrm{S}$ and $8^{\circ} \mathrm{S}$ ) and along the Fernando de Noronha chain (Figs. 11 and 12). A clear seasonal variability was observed with shallower limits for both variables in fall compared with spring (Figs. 10-12).

The MLD was shallower in A1 than in other areas with a sharp transition in the limit between A1 and A3 (Figs. 10-12). The BLT followed aa opposite pattern, with thicker BL in A1 than in other areas, although low values were also observed close to the shelf break. Some hotspots of high BLT ( $>40 \mathrm{~m})$ were observed in A1 in spring and in A1 and A3 in fall (Fig. 10). The BLT was in average thicker and the BLF higher in fall than spring (Table 2). More specifically, the BLF was the highest in A1 with $80 \%$ and $77 \%$ in spring and fall, respectively. A3 presented intermediate BLF values with $63 \%$ and $70 \%$ in spring and fall, respectively. The lowest BLF were observed in A2 with 14\% and 33\% in spring and fall, respectively. The seasonal and spatial patterns of the UTD were alike to the one of the MLD. The LTD presented a clear spatial pattern, shallow at low latitudes (A2, and in a lesser extent, A3) and deep close to the coast and in the extreme northwest of the study area (Figs. 10-12). In addition, small-scale vertical displacements of isotherms and isohalines were observed around islands and seamounts (Figs. 11c, $\mathrm{d}$ and $12 \mathrm{c}, \mathrm{d})$. 

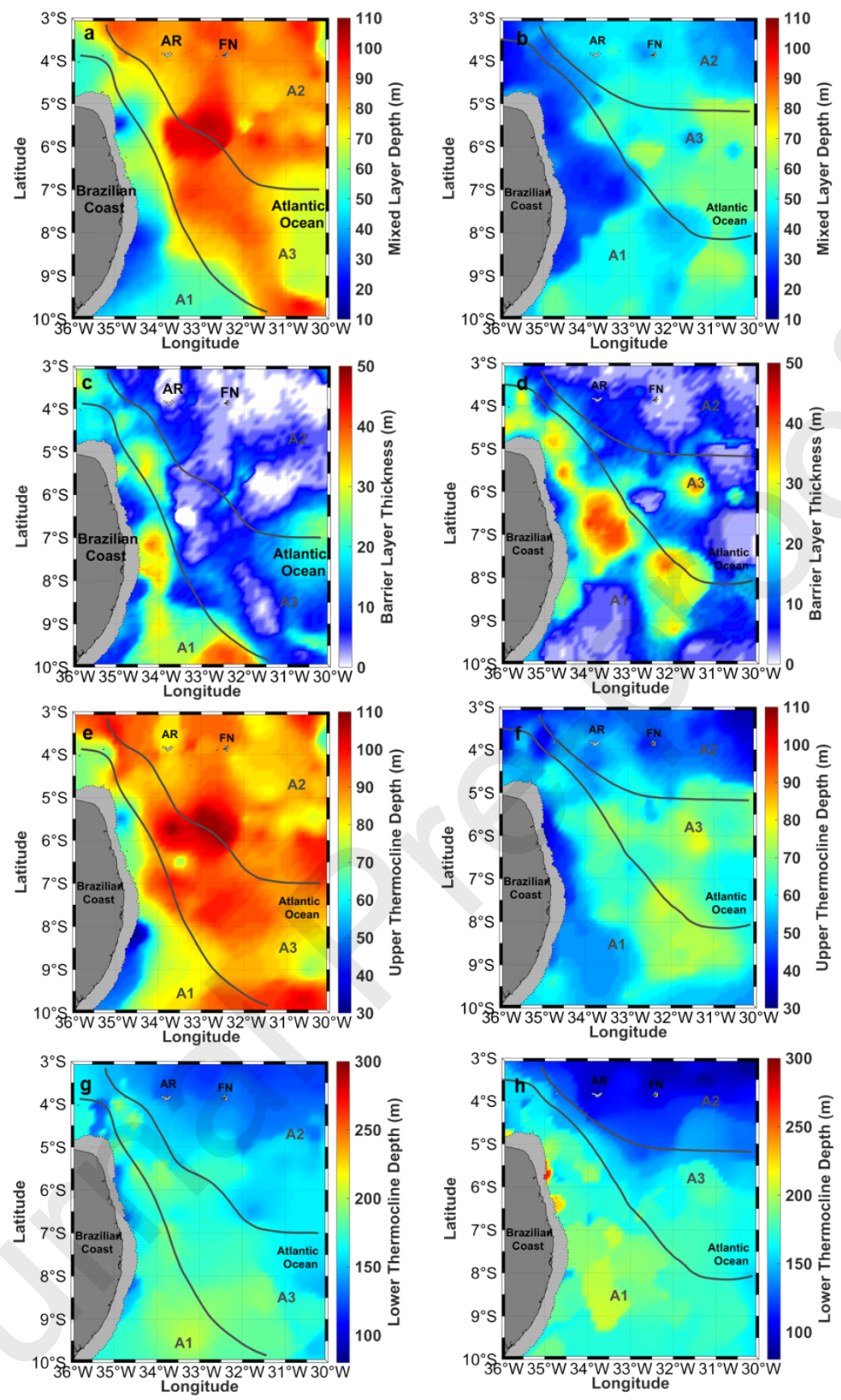

Figure 10. Thermohaline structure estimated from the interpolated temperature and salinity fields in spring (a, c, e, $\mathrm{g})$ and fall $(\mathrm{b}, \mathrm{d}, \mathrm{f}, \mathrm{h})$ in the southwestern tropical Atlantic. The panels show MLD (a, b); BLT (c, d); UTD (e, f) and LTD $(\mathrm{g}, \mathrm{h})$. Grey solid lines delimit areas A1, A2 and A3 defined in section 3.2. The continental shelf limited by the isobaths of $60 \mathrm{~m}$ is represented in light grey. RA: Rocas Atoll; FN: Fernando de Noronha archipelago. 
Table. 2. Characteristics of the thermohaline descriptors by area and by season from the smoothed original profiles and from interpolated fields (in parenthesis).

\begin{tabular}{|c|c|c|c|c|c|c|c|c|c|c|c|c|c|c|c|}
\hline & & \multicolumn{2}{|c|}{$\begin{array}{l}\text { Mixed layer depth } \\
(\mathrm{m})\end{array}$} & \multicolumn{2}{|c|}{$\begin{array}{l}\text { Barrier layer } \\
\text { thickness* }(\mathbf{m})\end{array}$} & \multicolumn{2}{|c|}{$\begin{array}{l}\text { Upper thermocline } \\
\text { depth (m) }\end{array}$} & \multicolumn{2}{|c|}{$\begin{array}{l}\text { Lower thermocline } \\
\text { depth (m) }\end{array}$} & \multicolumn{2}{|c|}{$\begin{array}{l}\text { Thermocline } \\
\text { thickness (m) }\end{array}$} & \multicolumn{2}{|c|}{ Maximum salinity } & \multicolumn{2}{|c|}{$\begin{array}{l}\text { Depth of maximum } \\
\text { salinity (m) }\end{array}$} \\
\hline & & S & F & S & F & S & F & S & F & $\mathrm{S}$ & $\mathrm{F}$ & & $\mathrm{F}$ & S & $\mathrm{F}$ \\
\hline \multirow{3}{*}{ Z } & Mdn & $58(60)$ & $36(46)$ & $18(16)$ & $20(16)$ & $76(80)$ & $60(58)$ & $175(180)$ & $168(168)$ & $104(100)$ & $110(110)$ & $37.2(37.1)$ & $37.2(37.1)$ & $92(92)$ & $80(82)$ \\
\hline & $\overline{\mathrm{m}}$ & $53(61)$ & $39(43)$ & $19(18)$ & $20(16)$ & $73(79)$ & $60(60)$ & 187 (177) & $173(171)$ & $104(100)$ & $114(112)$ & $37.2(37.1)$ & $37.2(37.1)$ & $92(90)$ & $78(84)$ \\
\hline & std & $16(16)$ & $15(11)$ & $12(9)$ & $15(11)$ & $18(13)$ & $13(9)$ & $37(15)$ & $24(11)$ & $26(18)$ & $28(14)$ & $0.1(0.1)$ & $0.2(0.1)$ & $16(8)$ & $24(20)$ \\
\hline \multirow{3}{*}{$\frac{1}{4}$} & Mdn & $92(84)$ & $46(44)$ & $2(2)$ & $2(4)$ & $94(86)$ & $48(48)$ & $134(130)$ & $98(102)$ & $40(44)$ & $48(52)$ & $36.7(36.5)$ & $36.4(36.4)$ & $98(100)$ & $66(66)$ \\
\hline & $\overline{\mathrm{m}}$ & $90(85)$ & $46(43)$ & $2(2)$ & $4(5)$ & $92(87)$ & $51(48)$ & $135(130)$ & 99 (104) & $43(44)$ & $48(55)$ & $36.7(36.5)$ & $36.4(36.4)$ & $100(99)$ & $68(66)$ \\
\hline & std & $7(4)$ & $11(4)$ & $3(3)$ & $4(3)$ & $9(4)$ & $10(5)$ & $12(8)$ & $13(13)$ & $12(9)$ & $10(12)$ & $0.1(0.1)$ & $0.2(0.2)$ & $7(3)$ & $12(9)$ \\
\hline \multirow{3}{*}{2} & Mdn & $85(84)$ & $55(56)$ & $7(8)$ & $8(10)$ & $94(92)$ & $65(66)$ & $178(174)$ & $160(156)$ & $88(76)$ & $94(88)$ & $37.0(36.8)$ & $36.8(36.7)$ & 107 (110) & $90(92)$ \\
\hline & $\overline{\mathrm{m}}$ & $82(82)$ & $52(55)$ & $10(10)$ & $12(11)$ & $92(92)$ & $64(66)$ & 179 (173) & $157(154)$ & $87(79)$ & $93(87)$ & $37.0(36.8)$ & $36.8(36.7)$ & $107(109)$ & $89(92)$ \\
\hline & std & $16(10)$ & $14(7)$ & $11(6)$ & $12(8)$ & $14(6)$ & $11(5)$ & $13(9)$ & $13(15)$ & $21(8)$ & $12(14)$ & $0.2(0.1)$ & $0.2(0.1)$ & $12(6)$ & $13(7)$ \\
\hline
\end{tabular}

$B L T^{*}$ The frequency of BLTs larger than $5 \mathrm{~m}$ was $80 \%$ (77\%), 14\% (33\%) and 63\% (70\%) in spring (fall) for A1, A2 and A3, respectively

$\mathrm{S}=$ spring; $\mathrm{F}=$ fall; $\mathrm{Mdn}=$ median; $\bar{m}=$ mean; $\mathrm{Std}=$ standard deviation 

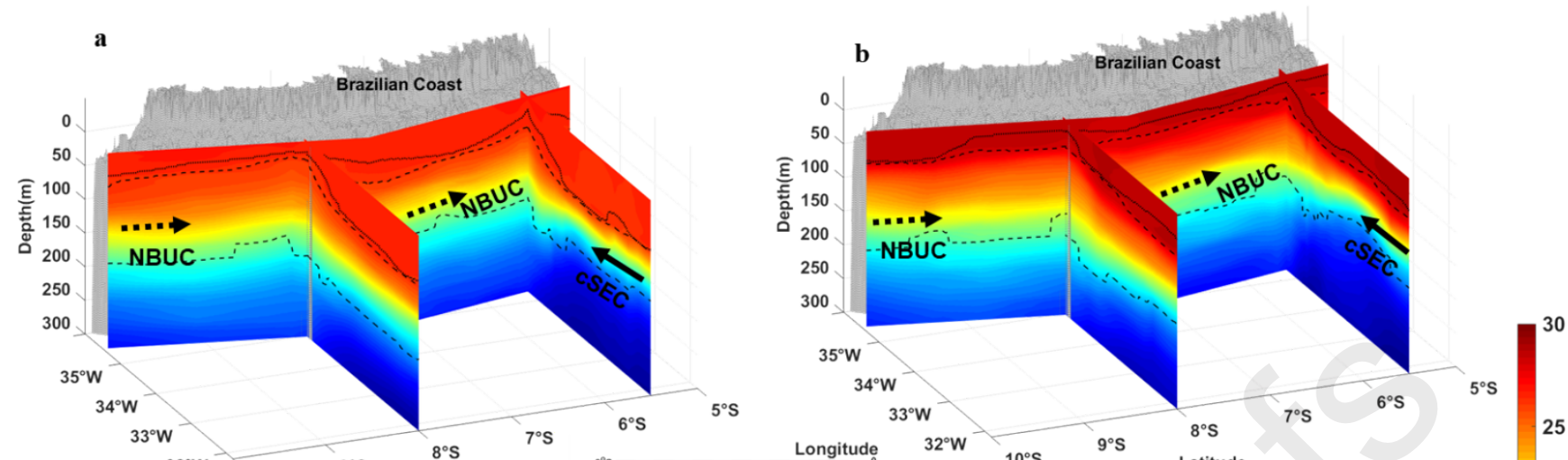

Longitude $\quad 32^{\circ} \mathrm{W} \quad{ }_{10}^{\circ} \quad 9^{\circ} \mathrm{S}_{\text {Latitude }}^{8^{\circ} \mathrm{S}}$
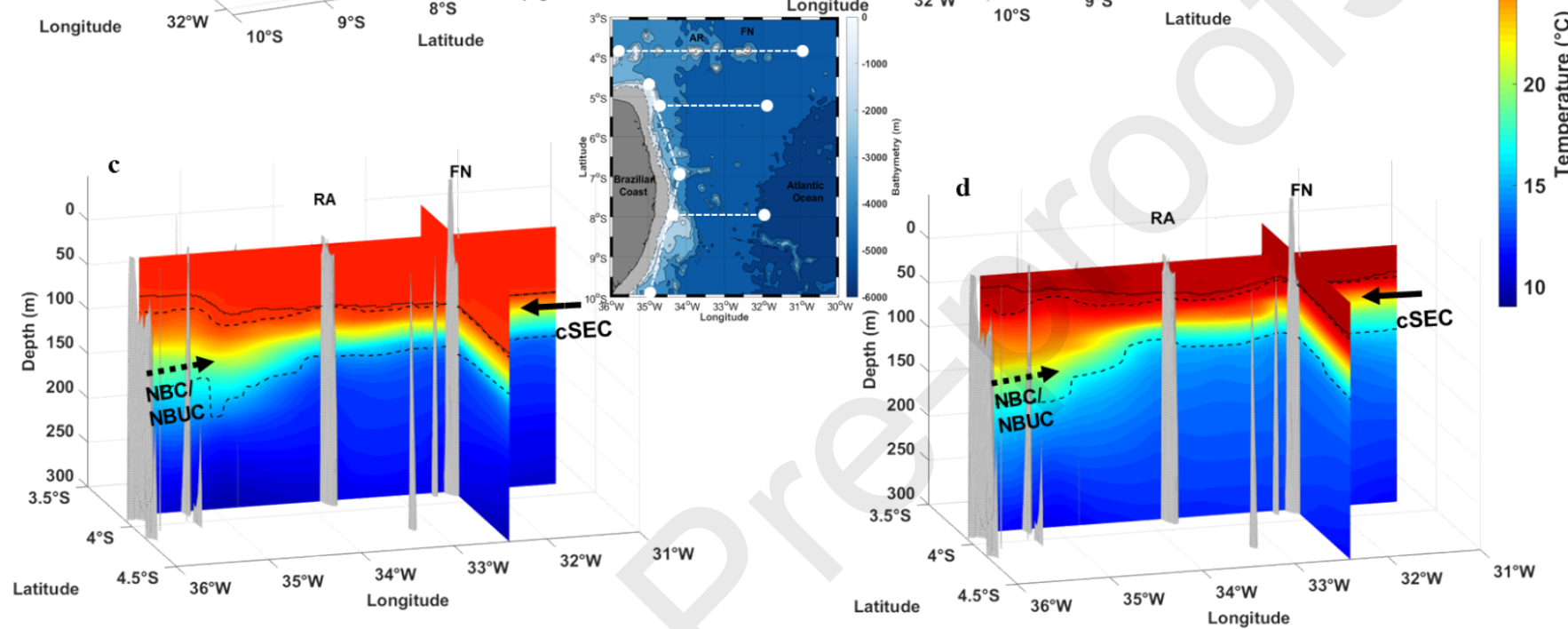

Figure 11. Vertical sections of temperature in spring (a, c) and fall (b, d). Sections in (a, b) include two along-shore transects $\left(9.95^{\circ} \mathrm{S} / 35^{\circ} \mathrm{W}-7.4^{\circ} \mathrm{S} / 34^{\circ} \mathrm{W}\right.$ and $\left.7.4^{\circ} \mathrm{S} / 34^{\circ} \mathrm{W}-4.7^{\circ} \mathrm{W} / 35^{\circ} \mathrm{W}\right)$ and two cross-shore transects $\left(8^{\circ} \mathrm{S} / 35-\right.$ $31.3^{\circ} \mathrm{W}$ and $\left.5.5^{\circ} \mathrm{S} / 35-31.3^{\circ} \mathrm{W}\right)$. Sections in $(\mathrm{d}, \mathrm{e})$ include a transect along $3.87^{\circ} \mathrm{S}$ from $36^{\circ} \mathrm{W}$ to $31^{\circ}$ and a transect crossing Fernando de Noronha island (FN) at $32.4^{\circ} \mathrm{W}$ from $3.5^{\circ} \mathrm{S}$ to $4.5^{\circ} \mathrm{S}$. The grey areas represent the relief; RA: Rocas Atoll; FN: Fernando de Noronha archipelago. The black solid lines show the MLD. The black dashed lines show the upper and lower limits of the thermocline. The difference between the MLD and the upper limit of the thermocline illustrates the presence of the BL. The main currents are represented. cSEC: central branch of the South Equatorial Current; NBUC: North Brazilian Undercurrent; NBC: North Brazilian Current. The central panel shows the localisation of the transects depicted in the 3D plots. 


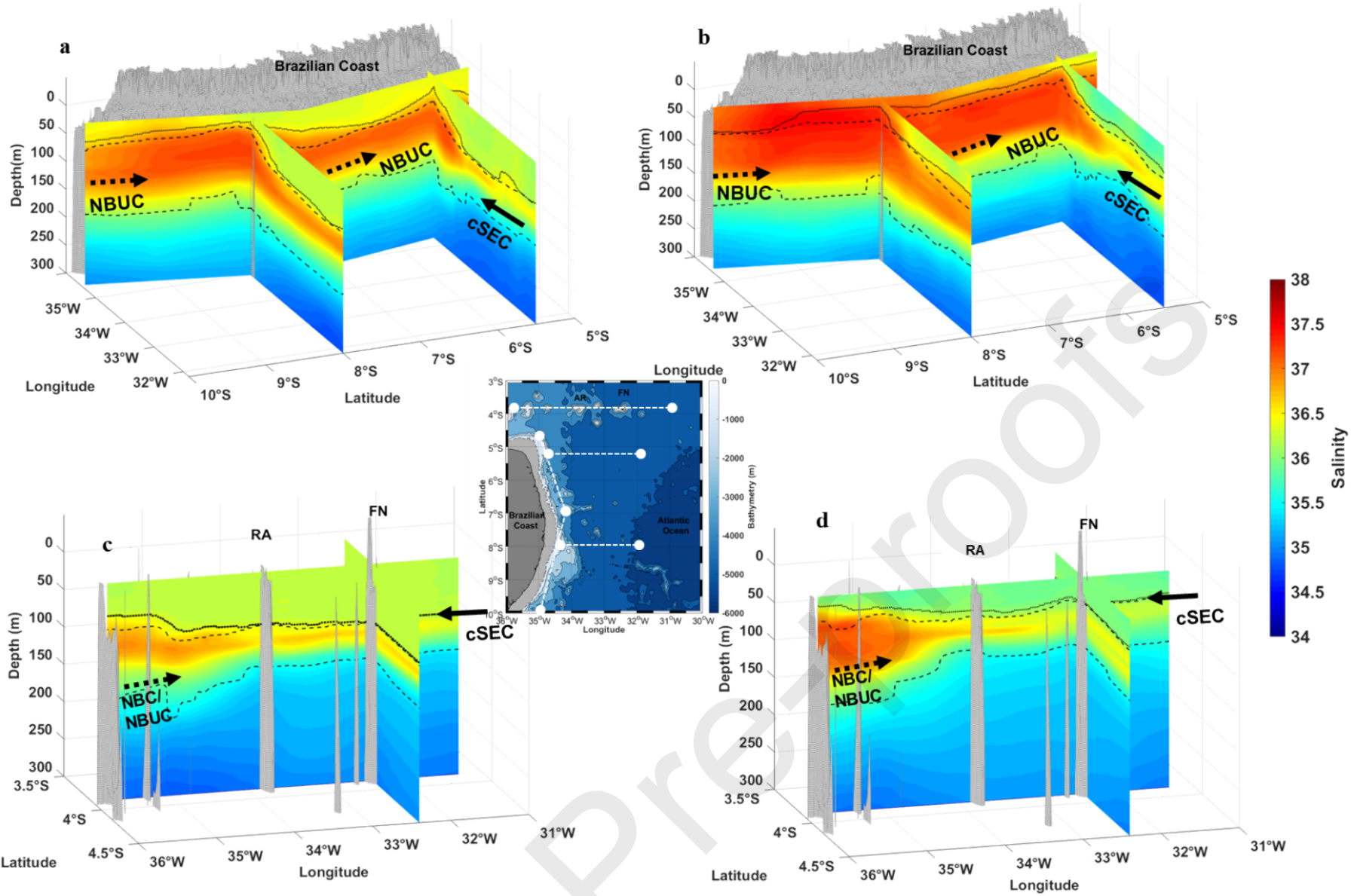

Figure 12. Vertical sections of salinity in spring $(a, c)$ and fall $(b, d)$. Sections in $(a, b)$ include two along-shore transects $\left(9.95^{\circ} \mathrm{S} / 35^{\circ} \mathrm{W}-7.4^{\circ} \mathrm{S} / 34^{\circ} \mathrm{W}\right.$ and $\left.7.4^{\circ} \mathrm{S} / 34^{\circ} \mathrm{W}-4.7^{\circ} \mathrm{W} / 35^{\circ} \mathrm{W}\right)$ and two cross-shore transects $\left(8^{\circ} \mathrm{S} / 35-\right.$ $31.3^{\circ} \mathrm{W}$ and $\left.5.5^{\circ} \mathrm{S} / 35-31.3^{\circ} \mathrm{W}\right)$. Section in $(\mathrm{d}, \mathrm{e})$ include a transect along $3.87^{\circ} \mathrm{S}$ from $36^{\circ} \mathrm{W}$ to $31^{\circ}$ and one transect crossing Fernando de Noronha island (FN) at $32.4^{\circ} \mathrm{W}$ from $3.5^{\circ} \mathrm{S}$ to $4.5^{\circ} \mathrm{S}$. The grey areas represent the relief. RA: Rocas Atoll; FN: Fernando de Noronha archipelago. The black solid line shows the MLD. The black dashed lines show the upper and lower limits of the thermocline. The difference between the MLD and the upper limit of the thermocline illustrate the presence of the BL. The main currents are represented. cSEC: central branch of the South Equatorial Current; NBUC. North Brazilian Undercurrent; NBC: North Brazilian Current. The central panel shows the localisation of the transects depicted in the 3D plots.

\subsubsection{Atmospheric forcing}

In spring, the E-P budget (Fig. 13a) is positive throughout the SWTA domain, with values reaching 6 $\mathrm{mm} . \mathrm{d}^{-1}$ in the offshore region, south of $8^{\circ} \mathrm{S}$. In fall (Fig. 13b), a north-south gradient occurs with negative E-P budget (freshwater inflow) north of $5^{\circ} \mathrm{S}$, mostly in A2 (Supplementary Figures S3). South of $\sim 6^{\circ} \mathrm{S}$ the E-P budget was positive (up to $4 \mathrm{~mm}^{\mathrm{d}} \mathrm{d}^{-1}$ ), but with lower values than in spring. 
Southeast trade winds (Fig. 13c, d) are stronger in spring $\left(7.3\right.$ to $\left.9 \mathrm{~m} . \mathrm{s}^{-1}\right)$ than in fall $\left(5.4\right.$ to $\left.7 \mathrm{~m} . \mathrm{s}^{-1}\right)$. In spring, weakest winds are observed in $\mathrm{A} 1$, south of $8^{\circ} \mathrm{S}$; while in fall, weakest winds are observed north of $\sim 5^{\circ} \mathrm{S}$ in $\mathrm{A} 2$, and strongest winds in the southeast region of the SWTA.
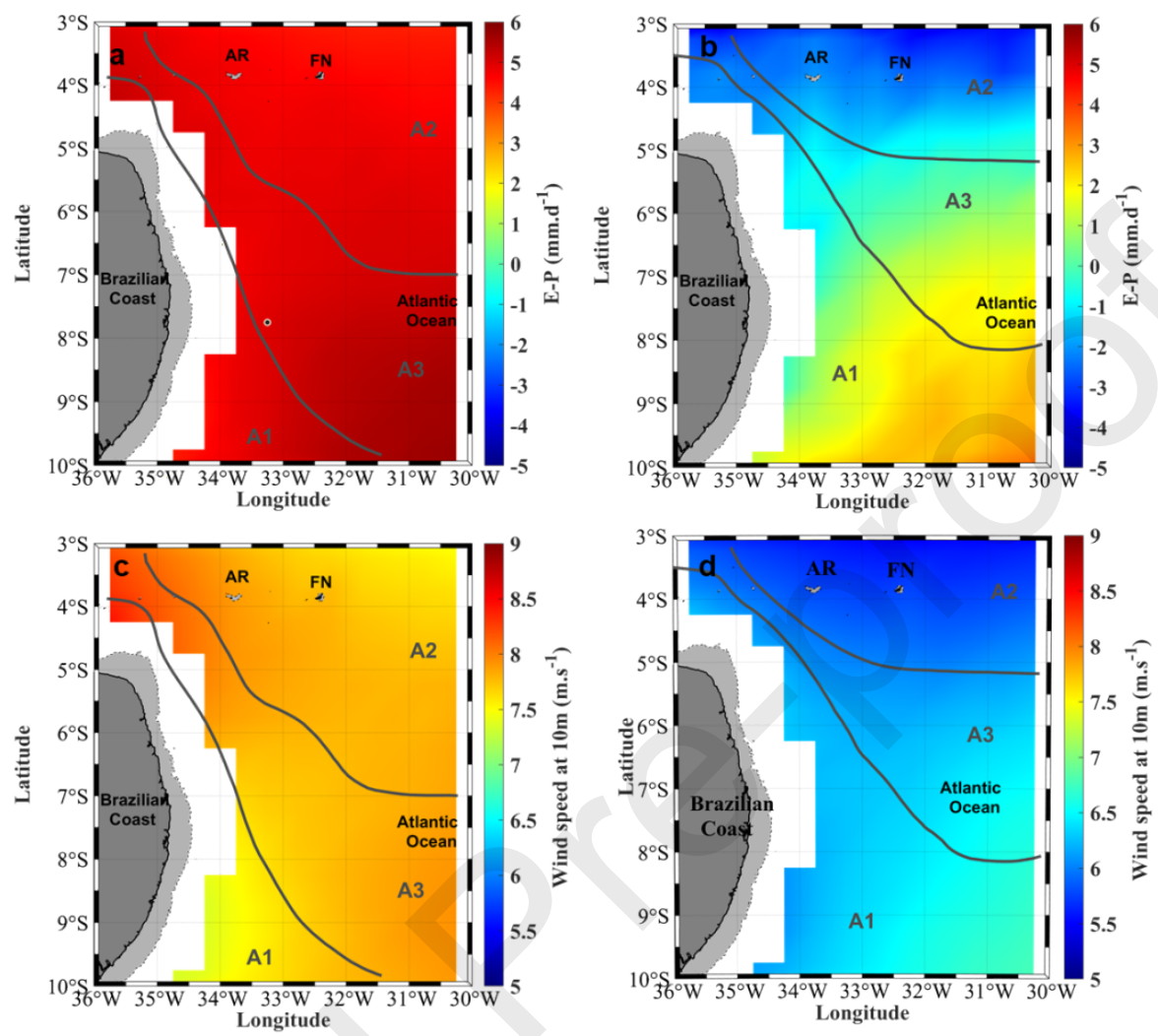

Figure 13. SWTA climatology evaporation minus precipitation budget (E-P) and wind speed at $10 \mathrm{~m}$ in spring (a, c) and fall (b, d) according to HOAPS data for 1988 to 2014. Grey solid lines delimit areas A1, $\mathrm{A} 2$ and $\mathrm{A} 3$ defined in section 3.2.

\section{Discussion}

Applying a FDA approach on CTD profiles from a variety of sources, we finely describe the canonical states of the thermohaline structure of the upper ocean of the SWTA in austral spring (Sept. - Oct.) and fall (Apr.- May). The application of an FDA approach has several advantages. First, it allows to explicitly consider the shape of the profiles (verticality) even when dealing with heterogenic data (Bayle et al., 2015; Pauthenet et al., 2017). For example, in our case most hydrographic profiles had regular sampling but some were irregular. In addition, fANOVA enable a statistical comparison of profiles (curves) that is not possible to achieve with classical methods. This allowed, for example, to objectively compare CTD profiles from different years and sources. The application of fANOVA did not reveal significant 
differences in temperature and salinity profiles between the reference set of data (ABRACOS) and ancillary data sets that span over the period 1983-2017 (Fig. 5). This result was not necessarily expected since Dommenget and Latif (2000) reported decadal variability in SST in the tropical Atlantic during 1903-1994. However, our study area, was one of the least affected by such variability (Dommenget and Latif, 2000). In the same way, an increase in salinity was observed in the last decades but such trend was lower in the South Atlantic central waters (Hummels et al., 2015). In addition, Dossa et al. (under review) showed that ocean circulation during ABRACOS periods was representative of the climatological data (1993-2018) for each season.

Second, FDA opens the way to robust and objective classification of thermohaline profiles (curves) that led us depicting areas statistically different and geographically separated. Third, the kriging of the profiles in a functional geostatistical framework was highly powerful to interpolate in $3 \mathrm{D}$ a high amount of in situ measurements and predictions considering explicitly the shape of all profiles.

Indeed, the FDA application using ordinary kriging with the assumption of stationarity led to consistent results (Fig. 7). In most cases, goodness of fit was very high with similar predictable and observed curves. Nevertheless, the presence of three areas with different thermohaline patterns led to some low adjustment (MSD - profile 4, Fig. 7) mostly in the boundaries between areas where some overlapping occurs (Fig. 6). This was expected since the boundaries between areas cannot be entirely steady. Considering the presence of 3 different areas in the SWTA demonstrating a lack of thermohaline stationarity in the SWTA domain, an alternative approach for future studies accounting for the no stationarity would be the use of Universal Kriging (Menafoglio et al., 2016, 2013), which supposes that the random field has an expectation that depends of the area.

\subsection{Thermohaline structure and associated processes}

By the application of the FDA, we reveal the complex panorama of the thermohaline structure in the SWTA. The portray of the canonical thermohaline structure illustrates seasonal differences with deeper MLD and thermocline in spring (Sept. - Oct.) than in fall (Apr.-May). In addition, we reveal the existence of three spatially delimited thermohaline provinces (A1, A2 and A3) with significant structural differences (Fig. 6) corresponding to different dynamical processes (atmospheric and oceanic). In most oceanic regions and in particular in the SWTA, a precise representation of the thermohaline structure is missing. This is due to a lack of spatial or temporal coverage. This prevents describing the actual spatiotemporal variability. In consequence, large areas encompassing a variety of conditions are often exemplified by a single TS diagram considered as representative (e.g. Tsuchiya et al., 1994). For example, Araujo et al. (2011) constructed TS diagram by latitudinal band encompassing areas that are significantly different as demonstrated in this study.

The overall seasonal differences we observed agree with the intraannual variability reported by early studies (Kara, 2003; Sato et al., 2006; Veneziani et al., 2014). It can be attributed to changes in mixing (wind stress), heat fluxes and the meridional displacement of the Intertropical Convergence Zone (ITCZ) (Biastoch et al., 2008; Hüttl and Böning, 2006; Lorbacher et al., 2006). In spring (Sep. - Oct.), the deeper MLD (Fig. 10a) and upper thermocline (Fig. 10e) are attributed to the negative surface heat flux and the lower SST (Fig. 8a) that increase the density of the surface layer (Veneziani et al., 2014). In addition, the 
strong winds (Fig. 13c) due northern position of the ITCZ at around $5^{\circ}-8^{\circ} \mathrm{N}$; Mignot et al. (2012), the elevated density and the improved mixing cause convective overturning of water, deepening the ML to a greater depth (Lorbacher et al., 2006; Tomczak and Godfrey, 1994). In turn, the shallower MLD (Fig. 10b) and upper thermocline (Fig. 10f) in fall (Apr. - May) (Fig. 8b) are a consequence of the gained buoyancy and higher SST due to the positive heat flux trend started since late spring (Lazar, 2002; Veneziani et al., 2014). This positive buoyancy is also coupled with the relaxation of southeastern trade winds (Fig. 13b) due the southmost position, $\sim 4^{\circ} \mathrm{N}$, of the ITCZ (Supplementary Figure S4; Colna, 2017), which shallows the MLD.

\section{Salinity}

The seasonal rate of change of salinity (Fig. 9) is not as marked as for temperature. However, the salinity meridional gradient observed at any depth with a reduction of salinity from A1 to A2 (Fig. 9) is sharper in fall than spring. Sea surface salinity (SSS) is mainly controlled by the E-P budget (Fig. 13a, b). In fall, this gradient is driven by the higher precipitation (Supplementary Figure S3) near the equatorial band related to the move back of the ITCZ towards the equator and the evaporation-dominated subtropics (Assunção et al., 2016; Awo et al., 2018; I Camara et al., 2015; Melzer and Subrahmanyam, 2017).

In subsurface (110 m and $200 \mathrm{~m}$, Fig. 9c-f), maximum salinity observed in A1 corresponds to the SUW (core salinity $>36.5$ ) advected by the NBUC (Dossa et al., under review); Stramma et al., 2005). Salinity vertical core was more extended in fall than spring all along A1 while evaporation is lower in fall in particular north of $8^{\circ} \mathrm{S}$ (Supplementary Figure S3). However, the SUW is originated by surface evaporation in the subtropical gyre region $\left(10^{\circ}-25^{\circ} \mathrm{S}\right)$ where E-P budget is always positive (Fig. 13 and Supplementary Figure S4). Salter water are then injected into the interior ocean and subsequently advected from the subtropical gyre to the SWTA region by the sSEC and the NBUC (Blanke et al., 2002; Bourlès et al., 1999; Mémery et al., 2000). There is therefore a delay between formation and entrance of saline waters in A1. Another factor, perhaps the most important, driving the vertical expansion of the salinity core in fall (Figs. 9 and 12) is the shoaling and the greater extension of the NBUC core (Dossa et al., under review; Schott et al., 1998; Silva et al., 2005; Stramma et al., 1995), increasing turbulence in surface layer and saline diffusion up to the ML. Our observations are coherent with Araujo et al. (2011) and Domingues et al. (2017) but the exact processes have yet to be elucidated.

\section{Barrier layer}

BLs were observed in the SWTA in both spring and fall in most of the study area. However, the BLT was lower than $5 \mathrm{~m}$ and "porous" in most (73\% in spring; 70\% in fall) of the study area. In such conditions, the BL cannot effectively obstruct the heat transfer (Mignot et al., 2009). Our results complement and clarify the observations identified by de Boyer Montégut et al. (2007) who indicated that BLs are quasipermanent in the western tropical Atlantic. However, this last study was global, with a grid of two degree, which can explain the difference with our fine-scale study at southwestern Atlantic.

The BLT was thick, reached up to $50 \mathrm{~m}$, in a band roughly conforming to the shape of the coast (Fig. $10 \mathrm{c}, \mathrm{d})$. This pattern can be primarily related to a higher influence of the SUW, which is entrained into the region within the NBC/NBUC system that flows northwestward along the Brazilian continental slope ( Dossa et al., under review; Stramma et al., 2005, 1995), in A1. In addition, sea surface salinity fronts 
induce the formation of BL (Sato et al., 2006; Veneziani et al., 2014). Thicker BLT (Fig. 11b) were indeed observed where salinity fronts occur (Fig. 9a, b), mainly on the fresh side of the fronts agreeing Sato et al. (2006, 2004) and Veneziani et al. (2014). Accordingly, it is in fall conditions, characterized by salty subsurface waters and striking salinity fronts, that the BLT was more preeminent, in particular in the 'frontal' central region (encompassing part of areas A1 and A3 between $6^{\circ} \mathrm{S}$ and $8^{\circ} \mathrm{S}$ ) of the SWTA.

\section{Diagnosing Areas 1, 2 and 3}

The three thermohaline domains (areas) share the same water-masses (Fig. 6e), but with different density range. Tropical South Water dominates in surface, the SUW in the upper part of the thermocline and the South Atlantic Central Water below. While each water-mass encompasses a large range of temperature or salinity conditions, considering water-masses only is not enough to portray the ocean characteristics in the study area. Our results show that more important are the actual values of temperature (Fig. 6a, c) and salinity (Fig. 6f, h) along sections between areas (also depicted by TS diagram, Fig. 6e). In the slope area (A1) where the maximum salinity values are observed (Fig. 6f, h), the thermocline is thick (Fig. 12a, c) with low static stability and thus stratification (Fig. 6j). This structure changes towards lower salinity (Fig. 6f, h), thinner thermocline (Fig. 6a, c), higher stability and stratification (Fig. 6j) when moving offshore and north with strong stratification in A2 and intermediate conditions in A3.

\section{Area 1 (A1)}

A1 corresponds to the western boundary system of the NBUC (Fig. 8) originated by the bifurcation of the sSEC at $\sim 12^{\circ}-20^{\circ} \mathrm{S}$ in the subsurface layer (Stramma and Schott, 1999). The NBUC flows northwards at a speed up to $1.2 \mathrm{~m} \cdot \mathrm{s}^{-1}$ along the continental slope with a core located within and below the thermocline (at 150-450 m; Dossa, et al., under review; Tomczak and Godfrey, 2001). This system forms part of the AMOC and is a crucial link within the southern wind-driven tropical-subtropical cell (Schott et al., 2005; Zheng et al 2003).

A1 encompasses the shallower MLD/UTD and the thickest thermocline (Table 2) associated with the lower thermic gradient and thus a weak stratification (Figs. 6, 8 and 11). As observed in other boundary systems (Preusse et al., 2010; Todd et al., 2016), the presence of strong western boundary currents (NBUC presents only in A1) reduces the static stability as illustrated by the shear instability $\left(\mathrm{N}^{2}\right.$ in Fig. 6j), promoting vertical salinity diffusion from the SUW to the isothermal layer. This process favours the formation of long-lasting BL in A1. The presence of thick BLs tends to shoal the MLD (de Boyer Montégut et al., 2007). However, close to the slope, some areas do not encompass thick BL (Fig. 10c, d) but still present shallow MLD/UTD, especially in spring. The shallowest MLD in A1 is likely driven by the NBUC water influx rising the thermocline. This process is magnified in spring by the proximity of the sSEC bifurcation (at $\sim 13^{\circ} \mathrm{S}$ ) causing intense mesoscale activities (Peterson and Stramma, 1991; Schott et al., 2005; Thévenin et al., 2019). Thus, in this area, NBUC-related oceanic processes seem to overwhelm atmospheric (wind) forcing, especially in the slope area.

\section{Area 2 (A2)}

A2 encompasses most of the Fernando de Noronha chain and is characterised by high static stability due to high buoyancy frequency (Fig. 6j) at the thermocline depth. This reflects the dominance of a 
relatively weak $\left(\sim 0.34 \mathrm{~m} . \mathrm{s}^{-1}\right)$ surface current $(\sim 0-100 \mathrm{~m})$, the cSEC (Fig. 11c, d), that carries water from the eastern Atlantic with lower salinity compared with the waters of the SWTA (Lumpkin and Garzoli, 2005; Peterson and Stramma, 1991). At the sub-thermocline, A2 is dominated by the eastward SEUC (Fig. 8 ), located between $3^{\circ} \mathrm{S}$ and $5^{\circ} \mathrm{S}$ (Goes et al., 2005) and supplied by the NBC/NBUC system (Goes et al., 2005; Stramma et al., 2005). Even under the influence of the SUW, A2 presents the lowest BLF of the study area. The increase in BLF from $14 \%$ in spring to $32 \%$ in fall can be explained by ITCZ-induced precipitations, hence negative E-P budget at low latitudes (Fig. 13b, Supplementary Figures S3 and S4; Awo et al., 2018; Da-Allada et al., 2013) decreasing the SSS (Fig. 9b).

The deeper MLD observed in spring can be associated with the negative heat flux, stronger winds (Fig. 13a; Sato et al., 2006) and low precipitation (Supplementary Figure S3a northern position of the ITCZ), leading to higher SSS and therefore higher density and convective overturning of the surface layer. In spring, the thermocline is also locally shallower downstream FN (Fig. 12d). These displacement could be originated by orographic influences on the cSEC (wake effect) as shown by Tchamabi et al. (2017). This orographic interaction reduces the thermocline depth, increasing nutrient supply and related biological production (Jales et al., 2015; Silva, 2018).

\section{Area 3 (A3)}

Overall, A3 acts as a transition zone and mixing of water bodies. Indeed, with an intermediate stratification pattern (Fig 6j) and, therefore, moderate static stability, A3 is still influenced by the western boundary system but is not directly affected by the NBUC. The northmost part of A3 is influenced by the westward flow of the southern limb of the $\operatorname{cSEC}\left(3^{\circ}-5^{\circ} \mathrm{S}\right.$, Molinari,1982). In fall, the low temperatures (Fig. 8e, f) and salinities (Fig. 9e,f) observed at $200 \mathrm{~m}$ along A3 could be originated by the advection of subsurface colder and less saline eastern Atlantic waters advected westwards with a $\sim 9 \mathrm{cms}^{-1}$ velocity near $7^{\circ} \mathrm{S}$ (Bourlès et al., 1999; Molinari, 1983, 1982).

\section{Conclusion}

This study shows that the application of an FDA approach on hydrographic data allows for a robust and precise characterising and estimation of the ocean thermohaline 3D structure. Even if based on a stationarity assumption for the mean function in a non-stationary context, our approach brought insights on the thermohaline structure of the tropical southwestern Atlantic. By characterising the canonical seasonal states of spring and fall in the SWTA, we reveal a clear spatial pattern with the presence of three areas with significantly different thermohaline structure. Area 1, mostly located along the continental slope, reflects the western boundary current system, with low static stability and high frequency of occurrence of barrier layer (BL). Conversely, Area 2, located along the Fernando de Noronha chain, presents strong static stability with a well-marked thermocline. This area is under the influence of the eastern Atlantic. It is characterised by a low BLF, which is seasonally modulated by the latitudinal oscillation of ITCZ, controlling the regime of precipitation. In turn, A3 behaves as a transition zone between $\mathrm{A} 1$ and $\mathrm{A} 2$ with still the presence of the water core of maximum salinity in subsurface, and therefore strong/moderate presence of BL. 
From our results, the spring and fall thermohaline structure of the upper ocean did not vary significantly during the last decades. However, the expected changes in AMOC circulation (Chang et al., 2008) should affect the 3D transport of heat, salt, as well as the regional distributions of water mass boundaries, and may lead to shifts in ecosystems (Foltz et al., 2019; Hummels et al., 2015). This work can thus serve as a reference for diagnosing future variations in the AMOC and subtropical-tropical cell variability.

On the basis of this and other studies (e.g. Pauthenet et al., 2019, 2017), FDA approach emerges as a powerful way to describe, characterise, classify and compare ocean patterns and processes. It can be applied to in situ data but could also be used to deeply and comprehensively explore ocean models outputs. Further, this approach is applicable to any fields where data are present in the form of curves.

\section{Acknowledgments}

We acknowledge the French oceanographic fleet for funding the at-sea survey and the officers and crew of the R/V Antea for their contribution to the success of the operations during the ABRACOS cruises. We thanks the Helmholtz-Zentrum für Ozeanforschung Kiel (GEOMAR) for PANGEA data availability. The Conselho Nacional de Desenvolvimento Científico e Tecnológico (CNPq) by supported through a PhD scholarship grant for Assunção, Ramilla. M.A. thanks the support of the Brazilian Research network on Global Climate Change FINEP/Rede CLIMA (grants 01.13.0353-00). This work is a contribution to the International Joint Laboratory TAPIOCA (www.tapioca.ird.fr), CAPES/COFECUB program (88881.142689/2017-01), PADDLE project (funding by the European Union's Horizon 2020 research and innovation programme - grant agreement No. 73427).

\section{References}

Andersson, A., Graw, K., Schröder, M., Fennig, K., Liman, J., Bakan, S., Hollmann, R., Klepp, C., 2017. Hamburg Ocean Atmosphere Parameters and Fluxes from Satellite Data - HOAPS 4.0 [WWW Document]. Satell. Appl. Facil. Clim. Monit. (CM SAF). https://doi.org/10.5676/EUM_SAF_CM/HOAPS/V002

Araujo, M., Limongi, C., Servain, J., Silva, M., Leite, F.S., Veleda, D., Lentini, C.A.D., 2011. Salinity-induced mixed and barrier layers in the southwestern tropical Atlantic Ocean off the northeast of Brazil. Ocean Sci. 7, 63-73. https://doi.org/10.5194/os-7-63-2011

Assunção, R. V., Silva, A.C., Martins, J., Flores Montes, M., 2016. Spatial-Temporal Variability of the Thermohaline Properties in the Coastal Region of Fernando de Noronha Archipelago, Brazil. J. Coast. Res. 75, 512-516. https://doi.org/10.2112/SI75-103.1

Awo, F.M., Alory, G., Da-Allada, C.Y., Delcroix, T., Jouanno, J., Kestenare, E., Baloïtcha, E., 2018. Sea Surface Salinity Signature of the Tropical Atlantic Interannual Climatic Modes. J. Geophys. Res. Ocean. 7420-7437. https://doi.org/10.1029/2018JC013837

Balaguru, K., Chang, P., Saravanan, R., Jang, C.J., 2012. The barrier layer of the Atlantic warmpool: formation mechanism and influence on the mean climate. Tellus A Dyn. Meteorol. Oceanogr. 64, 18162. https://doi.org/10.3402/tellusa.v64i0.18162

Bayle, S., Monestiez, P., Guinet, C., Nerini, D., 2015. Moving toward finer scales in oceanography: Predictive linear functional model of Chlorophyll a profile from light data. Prog. Oceanogr. 134, 221-231. https://doi.org/10.1016/j.pocean.2015.02.001

Bertrand, A., 2017. ABRACOS 2 cruise, RV Antea [WWW Document]. https://doi.org/10.17600/17004100

Bertrand, A., 2015. ABRACOS cruise, RV Antea [WWW Document]. https://doi.org/10.17600/15005600

Bertrand, A., Grados, D., Colas, F., Bertrand, S., Capet, X., Chaigneau, A., Vargas, G., Mousseigne, A., Fablet, R., 2014. 
Broad impacts of fine-scale dynamics on seascape structure from zooplankton to seabirds. Nat. Commun. 5. https://doi.org/10.1038/ncomms6239

Biastoch, A., Böning, C.W., Getzlaff, J., Molines, J.-M., Madec, G., 2008. Causes of Interannual-Decadal Variability in the Meridional Overturning Circulation of the Midlatitude North Atlantic Ocean. J. Clim. 21, 6599-6615. https://doi.org/10.1175/2008JCLI2404.1

Blanke, B., Arhan, M., Lazar, A., Prévost, G., 2002. A Lagrangian numerical investigation of the origins and fates of the salinity maximum water in the Atlantic. J. Geophys. Res. 107, 3163. https://doi.org/10.1029/2002JC001318

Boor, C. De, 2001. A practical guide to splines. Springer Handbooks Comput. Stat. 302.

Bourlès, B., Gouriou, Y., Chuchla, R., 1999. On the circulation in the upper layer of the western equatorial Atlantic. J. Geophys. Res. Ocean. 104, 21151-21170. https://doi.org/10.1029/1999JC900058

Bourles, B., Molinari, R.L., Johns, E., Wilson, W.D., Leaman, K.D., 1999. Upper layer currents in the western tropical North Atlantic (1989-1991). J. Geophys. Res. Ocean. 104, 1361-1375. https://doi.org/10.1029/1998JC900025

Brainerd, K.E., Gregg, M.C., 1995. Surface mixed and mixing layer depths. Deep. Res. Part I 42, 1521-1543. https://doi.org/10.1016/0967-0637(95)00068-H

Camara, I., Kolodziejczyk, N., Mignot, J., Lazar, A., Gaye, A.T., 2015. On the seasonal variations of salinity of the tropical Atlantic mixed layer. J. Geophys. Res. Ocean. 120, 4441-4462. https://doi.org/10.1002/2015JC010865

Camara, I, Kolodziejczyk, N., Mignot, J., Lazar, A., Gaye, A.T., 2015. On the seasonal variations of salinity of the tropical Atlantic mixed layer. J. Geophys. Res. Ocean. 120, 4441-4462. https://doi.org/10.1002/2015JC010865

Carranza, M.M., Gille, S.T., Franks, P.J.S., Johnson, K.S., Pinkel, R., Girton, J.B., 2018. When Mixed Layers Are Not Mixed. Storm-Driven Mixing and Bio-optical Vertical Gradients in Mixed Layers of the Southern Ocean. J. Geophys. Res. Ocean. 123, 7264-7289. https://doi.org/10.1029/2018JC014416

Chen, D., Busalacchi, A.J., Rothstein, L.M., 1994. The roles of vertical mixing, solar radiation, and wind stress in a model simulation of the sea surface temperature seasonal cycle in the tropical Pacific Ocean. J. Geophys. Res. 99, 20345. https://doi.org/10.1029/94JC01621

Colna, K.E., 2017. Latitudinal Position and Trends of the Intertropical Convergence Zone ( ITCZ ) and its Relationship with Upwelling in the Southern Caribbean Sea and Global Climate Indices. University of South Florida.

Cressie, N.A.C., 1993. Statistics for Spatial Data, Wiley Series in Probability and Statistics. John Wiley \& Sons, Inc., Hoboken, NJ, USA. https://doi.org/10.1002/9781119115151

Cuevas, A., Febrero, M., Fraiman, R., 2004. An anova test for functional data. Comput. Stat. Data Anal. 47, 111-122. https://doi.org/10.1016/J.CSDA.2003.10.021

Da-Allada, C.Y., Alory, G., Du Penhoat, Y., Kestenare, E., Durand, F., Hounkonnou, N.M., 2013. Seasonal mixed-layer salinity balance in the tropical Atlantic Ocean: Mean state and seasonal cycle. J. Geophys. Res. Ocean. 118, 332-345. https://doi.org/10.1029/2012JC008357

Dabo-Niang, S., Ferraty, F., 2008. Functional and Operatorial Statistics, Contributions to Statistics. Physica-Verlag HD, Heidelberg. https://doi.org/10.1007/978-3-7908-2062-1

de Boyer Montégut, C., Madec, G., Fischer, A.S., Lazar, A., Iudicone, D., 2004. Mixed layer depth over the global ocean: An examination of profile data and a profile-based climatology. J. Geophys. Res. C Ocean. 109, 1-20. https://doi.org/10.1029/2004JC002378

de Boyer Montégut, C., Mignot, J., Lazar, A., Cravatte, S., 2007. Control of salinity on the mixed layer depth in the world ocean: 1. General description. J. Geophys. Res. Ocean. 112, 1-12. https://doi.org/10.1029/2006JC003953

Dengler, M., Schott, F.A., Eden, C., Brandt, P., Fischer, J., Zantopp, R.J., 2004. Break-up of the Atlantic deep western boundary current into eddies at $8^{\circ} \mathrm{S}$. Nature 432, 1018-1020. https://doi.org/10.1038/nature03134

Domingues, E. de C., Schettini, C.A.F., Truccolo, E.C., Oliveira Filho, J.C. de, 2017. Hydrography and currents on the Pernambuco Continental Shelf. RBRH 22, e43. https://doi.org/10.1590/2318-0331.0217170027

Dommenget, D., Latif, M., 2000. Interannual to Decadal Variability in the Tropical Atlantic. J. Clim. 13, 777-792. https://doi.org/10.1175/1520-0442(2000)013<0777:ITDVIT>2.0.CO;2

Dossa, A.N., Costa, A., Morel, Y., Chaigneau, A., Eldin, G., Araujo, M., Bertrand, A., Under review. Western boundary circulation off Northeast Brazil. Prog. Oceanogr.

Febrero-Bande, M., Fuente, M.O. de la, 2012. Statistical Computing in Functional Data Analysis: The R Package fda.usc. J. Stat. Softw. 51, 1-28. https://doi.org/10.18637/jss.v051.i04

Foltz, G.R., Brandt, P., Richter, I., Rodríguez-Fonseca, B., Hernandez, F., Dengler, M., Rodrigues, R.R., Schmidt, J.O., Yu, 
L., Lefevre, N., Da Cunha, L.C., McPhaden, M.J., Araujo, M., Karstensen, J., Hahn, J., Martín-Rey, M., Patricola, C.M., Poli, P., Zuidema, P., Hummels, R., Perez, R.C., Hatje, V., Lübbecke, J.F., Polo, I., Lumpkin, R., Bourlès, B., Asuquo, F.E., Lehodey, P., Conchon, A., Chang, P., Dandin, P., Schmid, C., Sutton, A., Giordani, H., Xue, Y., Illig, S., Losada, T., Grodsky, S.A., Gasparin, F., Lee, T., Mohino, E., Nobre, P., Wanninkhof, R., Keenlyside, N., Garcon, V., Sánchez-Gómez, E., Nnamchi, H.C., Drévillon, M., Storto, A., Remy, E., Lazar, A., Speich, S., Goes, M., Dorrington, T., Johns, W.E., Moum, J.N., Robinson, C., Perruche, C., de Souza, R.B., Gaye, A.T., López-Parages, J., Monerie, P.A., Castellanos, P., Benson, N.U., Hounkonnou, M.N., Duhá, J.T., Laxenaire, R., Reul, N., 2019. The Tropical Atlantic Observing System. Front. Mar. Sci. 6. https://doi.org/10.3389/fmars.2019.00206

Gasparin, F., Maes, C., Sudre, J., Garcon, V., Ganachaud, A., 2014. Water mass analysis of the Coral Sea through an Optimum Multiparameter method. J. Geophys. Res. Ocean. 119, 7229-7244. https://doi.org/10.1002/2014JC010246

Giraldo, R., Delicado Useros, P.F., Mateu, J., 2007. Geostatistics for functional data: an ordinary kriging approach.

Goes, M., Molinari, R., Da Silveira, I., Wainer, I., 2005. Retroflections of the North Brazil Current during February 2002. Deep. Res. Part I Oceanogr. Res. Pap. 52, 647-667. https://doi.org/10.1016/j.dsr.2004.10.010

Grados, D., Bertrand, A., Colas, F., Echevin, V., Chaigneau, A., Gutiérrez, D., Vargas, G., Fablet, R., 2016. Spatial and seasonal patterns of fine-scale to mesoscale upper ocean dynamics in an Eastern Boundary Current System. Prog. Oceanogr. 142, 105-116. https://doi.org/10.1016/j.pocean.2016.02.002

Hadjipantelis, P.Z., Müller, H.-G., 2018. Functional Data Analysis for Big Data: A Case Study on California Temperature Trends, in: Springer Handbooks of Computational Statistics. pp. 457-483. https://doi.org/10.1007/978-3-319-18284$1 \_18$

Halpern, D., 2002. Offshore Ekman transport and Ekman pumping off Peru during the 1997-1998 El Niño. Geophys. Res. Lett. 29, 19-1-19-4. https://doi.org/10.1029/2001GL014097

Holte, J., Talley, L., 2009. A new algorithm for finding mixed layer depths with applications to argo data and subantarctic mode water formation. J. Atmos. Ocean. Technol. 26, 1920-1939. https://doi.org/10.1175/2009JTECHO543.1

Hounsou-gbo, G.A., Araujo, M., Bourlès, B., Veleda, D., Servain, J., 2015. Tropical Atlantic Contributions to Strong Rainfall Variability Along the Northeast Brazilian Coast. Adv. Meteorol. 2015, 1-13. https://doi.org/10.1155/2015/902084

Hummels, R., Brandt, P., Dengler, M., Fischer, J., Araujo, M., Veleda, D., Durgadoo, J. V., 2015. Interannual to decadal changes in the western boundary circulation in the Atlantic at $11^{\circ} \mathrm{S}$. Geophys. Res. Lett. 42, 7615-7622. https://doi.org/10.1002/2015GL065254

Hüttl, S., Böning, C.W., 2006. Mechanisms of decadal variability in the shallow subtropical-tropical circulation of the Atlantic Ocean: A model study. J. Geophys. Res. 111, C07011. https://doi.org/10.1029/2005JC003414

Jales, M.C., Feitosa, F.A. do N., Koening, M.L., Montes, M. de J.F., Araújo Filho, M.C. de, Silva, R.A. da, 2015. Phytoplankton biomass dynamics and environmental variables around the Rocas Atoll Biological Reserve, South Atlantic. Brazilian J. Oceanogr. 63, 443-454. https://doi.org/10.1590/S1679-87592015093906304

Jamshidi, S., 2017. Assessment of thermal stratification, stability and characteristics of deep water zone of the southern Caspian Sea. J. Ocean Eng. Sci. 2, 203-216. https://doi.org/10.1016/j.joes.2017.08.005

Jang, C.J., Park, J., Park, T., Yoo, S., 2011. Response of the ocean mixed layer depth to global warming and its impact on primary production: a case for the North Pacific Ocean. ICES J. Mar. Sci. 68, 996-1007. https://doi.org/10.1093/icesjms/fsr064

Johnston, T.M.S., Rudnick, D.L., 2009. Observations of the Transition Layer. J. Phys. Oceanogr. 39, 780-797. https://doi.org/10.1175/2008JPO3824.1

Kara, A.B., 2003. Mixed layer depth variability over the global ocean. J. Geophys. Res. 108, 3079. https://doi.org/10.1029/2000JC000736

Ker, S., Le Gonidec, Y., Marié, L., 2016. Multifrequency seismic detectability of seasonal thermoclines assessed fromARGO data. J. Geophys. Res. Ocean. 3741-3756. https://doi.org/10.1002/2015JC011228.Received

Ker, S., Le Gonidec, Y., Marié, L., Thomas, Y., Gibert, D., 2015. Multiscale seismic reflectivity of shallow thermoclines. J. Geophys. Res. Ocean. 120, 1872-1886. https://doi.org/10.1002/2014JC010478

Kim, H.-J., Miller, A.J., 2007. Did the Thermocline Deepen in the California Current after the 1976/77 Climate Regime Shift? J. Phys. Oceanogr. 37, 1733-1739. https://doi.org/10.1175/jpo3058.1

Kraus, E.B. (Eric B., Businger, J.A., 1994. Atmosphere-ocean interaction. Oxford University Press.

Lambert, R.B., Sturges, W., 1977. A thermohaline staircase and vertical mixing in the thermocline. Deep Sea Res. 24, 211222. https://doi.org/10.1016/S0146-6291(77)80001-5 
Lazar, A., 2002. Seasonality of the ventilation of the tropical Atlantic thermocline in an ocean general circulation model. J. Geophys. Res. 107, 3104. https://doi.org/10.1029/2000JC000667

Liu, C., Köhl, A., Liu, Z., Wang, F., Stammer, D., 2016. Deep-reaching thermocline mixing in the equatorial pacific cold tongue. Nat. Commun. 7. https://doi.org/10.1038/ncomms11576

Liu, Z., 1993. Thermocline Forced by Varying Ekman Pumping. Part II: Annual and Decadal Ekman Pumping. J. Phys. Oceanogr. 23, 2523-2540. https://doi.org/10.1175/1520-0485(1993)023

Lorbacher, K., Dommenget, D., Niiler, P.P., Köhl, A., 2006. Ocean mixed layer depth: A subsurface proxy of oceanatmosphere variability. J. Geophys. Res. 111, C07010. https://doi.org/10.1029/2003JC002157

Lukas, R., Lindstrom, E., 1991. The mixed layer of the western equatorial Pacific Ocean. J. Geophys. Res. 96, 3343. https://doi.org/10.1029/90JC01951

Lumpkin, R., Garzoli, S.L., 2005. Near-surface circulation in the Tropical Atlantic Ocean. Deep Sea Res. Part I Oceanogr. Res. Pap. 52, 495-518. https://doi.org/10.1016/j.dsr.2004.09.001

Madhupratap, M., Nair, V.R., Sreekumaran Nair, S.R., Achuthankutty, C.T., 1981. Thermocline $\{\&\}$ zooplankton distribution. Indian J. Mar. Sci. 10, 262-265.

Maes, C., O'Kane, T.J., 2014. Seasonal variations of the upper ocean salinity stratification in the Tropics. J. Geophys. Res. Ocean. 119, 1706-1722. https://doi.org/10.1002/2013JC009366

Matheron, G., 1963. Principles of geostatistics. Econ. Geol. 58, 1246-1266. https://doi.org/10.2113/gsecongeo.58.8.1246

Melzer, B.A., Subrahmanyam, B., 2017. Decadal changes in salinity in the oceanic subtropical gyres. J. Geophys. Res. Ocean. 122, 336-354. https://doi.org/10.1002/2016JC012243

Mémery, L., Arhan, M., Alvarez-Salgado, X.A., Messias, M.J., Mercier, H., Castro, C.G., Rios, A.F., 2000. The water masses along the western boundary of the south and equatorial Atlantic. Prog. Oceanogr. https://doi.org/10.1016/S0079-6611(00)00032-X

Menafoglio, A., Grujic, O., Caers, J., 2016. Universal Kriging of functional data: Trace-variography vs cross-variography? Application to gas forecasting in unconventional shales. Spat. Stat. 15, 39-55. https://doi.org/10.1016/j.spasta.2015.12.003

Menafoglio, A., Secchi, P., Dalla Rosa, M., 2013. A Universal Kriging predictor for spatially dependent functional data of a Hilbert Space. Electron. J. Stat. 7, 2209-2240. https://doi.org/10.1214/13-EJS843

Mignot, J., de Boyer Montégut, C., Tomczak, M., 2009. On the porosity of barrier layers. Ocean Sci. 5, 379-387. https://doi.org/10.5194/os-5-379-2009

Mignot, J., Lazar, A., Lacarra, M., 2012. On the formation of barrier layers and associated vertical temperature inversions: A focus on the northwestern tropical Atlantic. J. Geophys. Res. Ocean. 117, 1-11. https://doi.org/10.1029/2011JC007435

Molinari, R.L., 1983. Observations of near-surface currents and temperature in the central and western tropical Atlantic Ocean. J. Geophys. Res. 88, 4433. https://doi.org/10.1029/JC088iC07p04433

Molinari, R.L., 1982. Observations of Eastward Currents in the Tropical South Atlantic Ocean: 1978-1980. J. Geophys. Res. 87, 9707-9714.

Nerini, D., Monestiez, P., Manté, C., 2010. Cokriging for spatial functional data. J. Multivar. Anal. 101, 409-418. https://doi.org/10.1016/j.jmva.2009.03.005

Pailler, K., Bourlès, B., Gouriou, Y., 1999. The barrier layer in the western tropical Atlantic ocean. Geophys. Res. Lett. 26, 2069-2072. https://doi.org/10.1029/1999GL900492

Pauthenet, E., Roquet, F., Madec, G., Nerini, D., 2017. A Linear Decomposition of the Southern Ocean Thermohaline Structure. J. Phys. Oceanogr. 47, 29-47. https://doi.org/10.1175/JPO-D-16-0083.1

Pauthenet, E., Roquet, F., Madec, G., Sallée, J.-B., Nerini, D., 2019. The Thermohaline Modes of the Global Ocean. J. Phys. Oceanogr. 49, 2535-2552. https://doi.org/10.1175/jpo-d-19-0120.1

Peterson, R.G., Stramma, L., 1991. Upper-level circulation in the South Atlantic Ocean. Prog. Oceanogr. 26, 1-73. https://doi.org/10.1016/0079-6611(91)90006-8

Preusse, M., Peeters, F., Lorke, A., 2010. Internal waves and the generation of turbulence in the thermocline of a large lake. Limnol. Oceanogr. 55, 2353-2365. https://doi.org/10.4319/lo.2010.55.6.2353

Rahter, B.A., 2010. Turbulent Dissipation in the Mid-Latitude Mixed Layer / Thermocline Transition Layer.

Ramsay, J.O., 2006. Functional Data Analysis, in: Encyclopedia of Statistical Sciences. John Wiley \& Sons, Inc., Hoboken, NJ, USA, pp. 675-678. https://doi.org/10.1002/0471667196.ess3138

Reyes, A., Giraldo, R., Mateu, J., 2015. Residual kriging for functional spatial prediction of salinity curves. Commun. Stat. - 
Theory Methods 44, 798-809. https://doi.org/10.1080/03610926.2012.753087

Rippert, N., Baumann, K.-H., Patzold, J., 2015. Thermocline fluctuations in the western tropical Indian Ocean during the past 35 ka 30, 201-210. https://doi.org/10.1002/jqs.2767

Rodrigues, R.R., Rothstein, L.M., Wimbush, M., 2007. Seasonal Variability of the South Equatorial Current Bifurcation in the Atlantic Ocean: A Numerical Study. J. Phys. Oceanogr. 37, 16-30. https://doi.org/10.1175/JPO2983.1

Sato, K., Suga, T., Hanawa, K., 2006. Barrier layers in the subtropical gyres of the world's oceans. Geophys. Res. Lett. 33, 8-11. https://doi.org/10.1029/2005GL025631

Sato, K., Suga, T., Hanawa, K., 2004. Barrier layer in the North Pacific subtropical gyre. Geophys. Res. Lett. 31, n/a-n/a. https://doi.org/10.1029/2003GL018590

Schott, F.A., Dengler, M., Zantopp, R., Stramma, L., Fischer, J., Brandt, P., 2005. The Shallow and Deep Western Boundary Circulation of the South Atlantic at $5^{\circ}-11^{\circ} \mathrm{S}$. J. Phys. Oceanogr. 35, 2031-2053. https://doi.org/10.1175/JPO2813.1

Schott, F.A., Fischer, J., Stramma, L., 1998. Transports and Pathways of the Upper-Layer Circulation in the Western Tropical Atlantic. J. Phys. Oceanogr. 28, 1904-1928. https://doi.org/10.1175/1520-0485(1998)028<1904:TAPOTU>2.0.CO;2

Shang, H.L., 2014. A survey of functional principal component analysis. AStA Adv. Stat. Anal. 98, 121-142. https://doi.org/10.1007/s10182-013-0213-1

Silva, A., Araujo, M., Medeiros, C., Silva, M., Bourlès, B., 2005. Seasonal changes in the mixed and barrier layers in the western Equatorial Atlantic. Brazilian J. Oceanogr. 53, 83-98. https://doi.org/10.1590/S1679-87592005000200001

Silva, B.J., 2018. Caracterização Do Sistema Carbonato No Arquipélago De Fernando De Noronha. Universidade Federal de Pernambuco.

Silva, M., Araujo, M., Servain, J., Penven, P., Lentini, C.A.D., 2009. High-resolution regional ocean dynamics simulation in the southwestern tropical Atlantic. Ocean Model. 30, 256-269. https://doi.org/10.1016/j.ocemod.2009.07.002

Sprintall, J., Cronin, M.F., 2010. Upper Ocean Vertical Structure. Encycl. Ocean Sci. 217-224. https://doi.org/10.1016/B978012374473-9.00627-5

Sprintall, J., Tomczak, M., 1992. Evidence of the barrier layer in the surface layer of the tropics. J. Geophys. Res. 97, 7305. https://doi.org/10.1029/92JC00407

Stramma, L., England, M., 1999. On the water masses and mean circulation of the South Atlantic Ocean. J. Geophys. Res. Ocean. 104, 20863-20883. https://doi.org/10.1029/1999JC900139

Stramma, L., Fischer, J., Reppin, J., 1995. The North Brazil Undercurrent. Deep Sea Res. Part I Oceanogr. Res. Pap. 42, 773795. https://doi.org/10.1016/0967-0637(95)00014-W

Stramma, L., Rhein, M., Brandt, P., Dengler, M., Böning, C., Walter, M., 2005. Upper ocean circulation in the western tropical Atlantic in boreal fall 2000. Deep Sea Res. Part I Oceanogr. Res. Pap. 52, 221-240. https://doi.org/10.1016/j.dsr.2004.07.021

Stramma, L., Schott, F., 1999. The mean flow field of the tropical Atlantic Ocean. Deep Sea Res. Part II Top. Stud. Oceanogr. 46, 279-303. https://doi.org/10.1016/S0967-0645(98)00109-X

Sun, O.M., Jayne, S.R., Polzin, K.L., Rahter, B.A., St. Laurent, L.C., 2013. Scaling Turbulent Dissipation in the Transition Layer. J. Phys. Oceanogr. 43, 2475-2489. https://doi.org/10.1175/JPO-D-13-057.1

Sverdrup, H.U., 1953. On Conditions for the Vernal Blooming of Phytoplankton. ICES J. Mar. Sci. 18, 287-295. https://doi.org/10.1093/icesjms/18.3.287

Swenson, M.S., Hansen, D. V., 1999. Tropical Pacific Ocean Mixed Layer Heat Budget: The Pacific Cold Tongue MARK. J. Phys. Oceanogr. 29, 371-398. https://doi.org/10.1007/978-3-319-15129-8_16

Tanguy, Y., Arnault, S., Lattes, P., 2010. Isothermal, mixed, and barrier layers in the subtropical and tropical Atlantic Ocean during the ARAMIS experiment. Deep Sea Res. Part I Oceanogr. Res. Pap. 57, 501-517. https://doi.org/10.1016/j.dsr.2009.12.012

Tchamabi, C.C., Araujo, M., Silva, M., Bourlès, B., 2017. A study of the Brazilian Fernando de Noronha Island and Rocas Atoll wakes in the tropical Atlantic. Ocean Model. https://doi.org/10.1016/j.ocemod.2016.12.009

Thévenin, M.R., Pereira, J., Lessa, G.C., 2019. Shelf-break upwelling on a very narrow continental shelf adjacent to a western boundary current formation zone. J. Mar. Syst. 194, 52-65. https://doi.org/10.1016/j.jmarsys.2019.02.008

Todd, R.E., Owens, W.B., Rudnick, D.L., 2016. Potential Vorticity Structure in the North Atlantic Western Boundary Current from Underwater Glider Observations. J. Phys. Oceanogr. 46, 327-348. https://doi.org/10.1175/JPO-D-150112.1

Tomczak, M., Godfrey, J.S., 1994. Regional Oceanography, 1st ed, Regional Oceanography. Elsevier. 
https://doi.org/10.1016/C2009-0-14825-0

Tsuchiya, M., Talley, L.D., McCartney, M.S., 1994. Water-mass distributions in the western South Atlantic; A section from South Georgia Island (54S) northward across the equator. J. Mar. Res. 52, 55-81. https://doi.org/10.1357/0022240943076759

Urbano, D.F., De Almeida, R.A.F., Nobre, P., 2008. Equatorial Undercurrent and North Equatorial Countercurrent at $38^{\circ} \mathrm{W}$ : A new perspective from direct velocity data. J. Geophys. Res 113, 4041. https://doi.org/10.1029/2007JC004215

Veneziani, M., Griffa, A., Garraffo, Z., Mensa, J.A., 2014. Barrier Layers in the Tropical South Atlantic: Mean Dynamics and Submesoscale Effects*. J. Phys. Oceanogr. 44, 265-288. https://doi.org/10.1175/JPO-D-13-064.1

Wackernagel, H., 2003. Multivariate Geostatistics : an Introduction with Applications. Springer Berlin Heidelberg.

Williams, B., Grottoli, A.G., 2010. Recent shoaling of the nutricline and thermocline in the western tropical Pacific. Geophys. Res. Lett. 37, 2-6. https://doi.org/10.1029/2010GL044867

Zeng, L., Wang, D., 2017. Seasonal variations in the barrier layer in the South China Sea: characteristics, mechanisms and impact of warming. Clim. Dyn. 48, 1911-1930. https://doi.org/10.1007/s00382-016-3182-8

Zhang, D., McPhaden, M.J., Johns, W.E., 2003. Observational Evidence for Flow between the Subtropical and Tropical Atlantic: The Atlantic Subtropical Cells*. J. Phys. Oceanogr. 33, 1783-1797. https://doi.org/10.1175/2408.1 


\section{Supplementary figures}
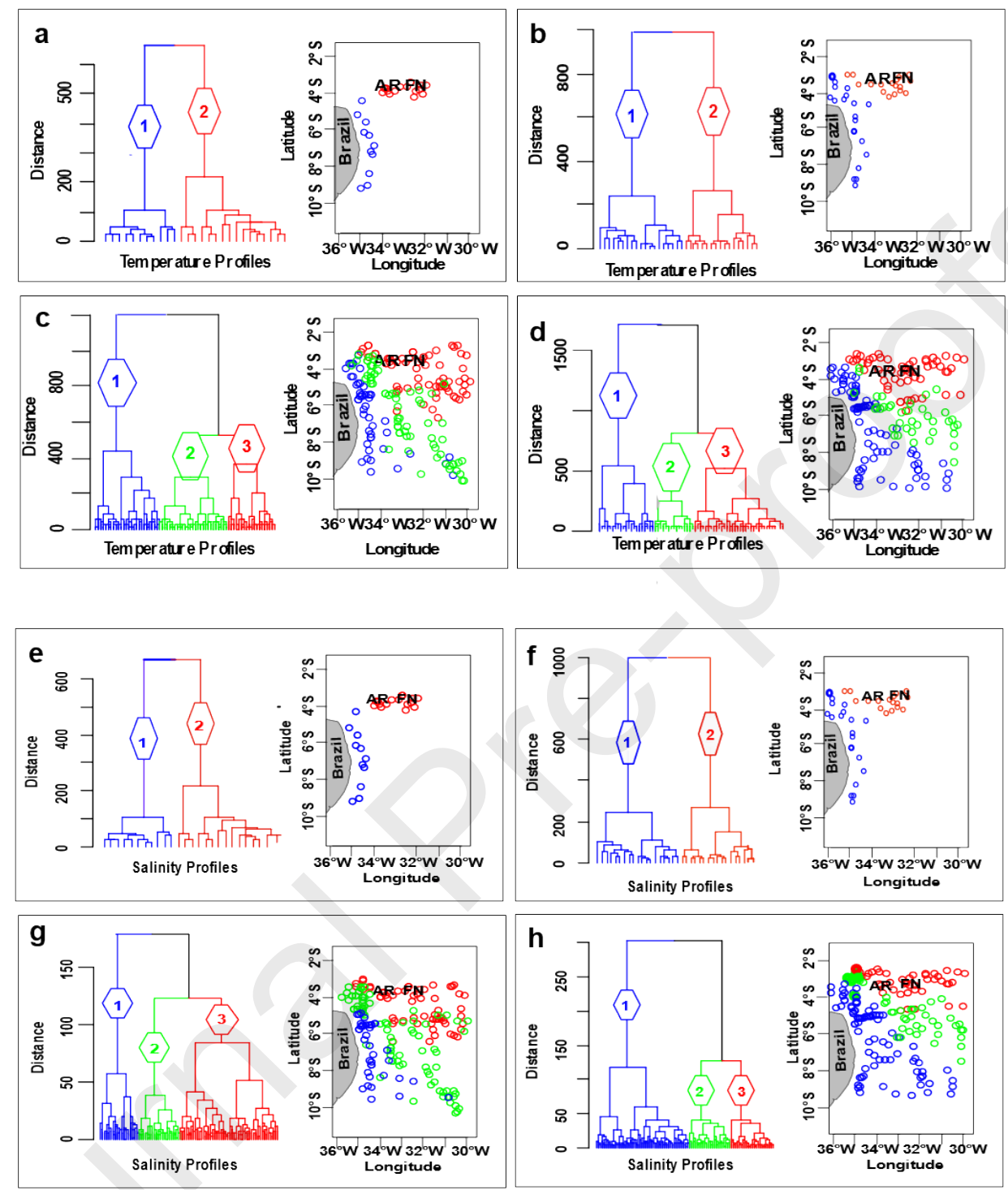

Figure S1. Dendrograms and spatial distribution of the classes/area for spring (a, c, e, g) and fall (b, d, f, h) for temperature $(\mathrm{a}-\mathrm{d})$ and salinity $(\mathrm{e}-\mathrm{h})$. Blue, red and green colours represent Areas 1,2 and 3, respectively. 

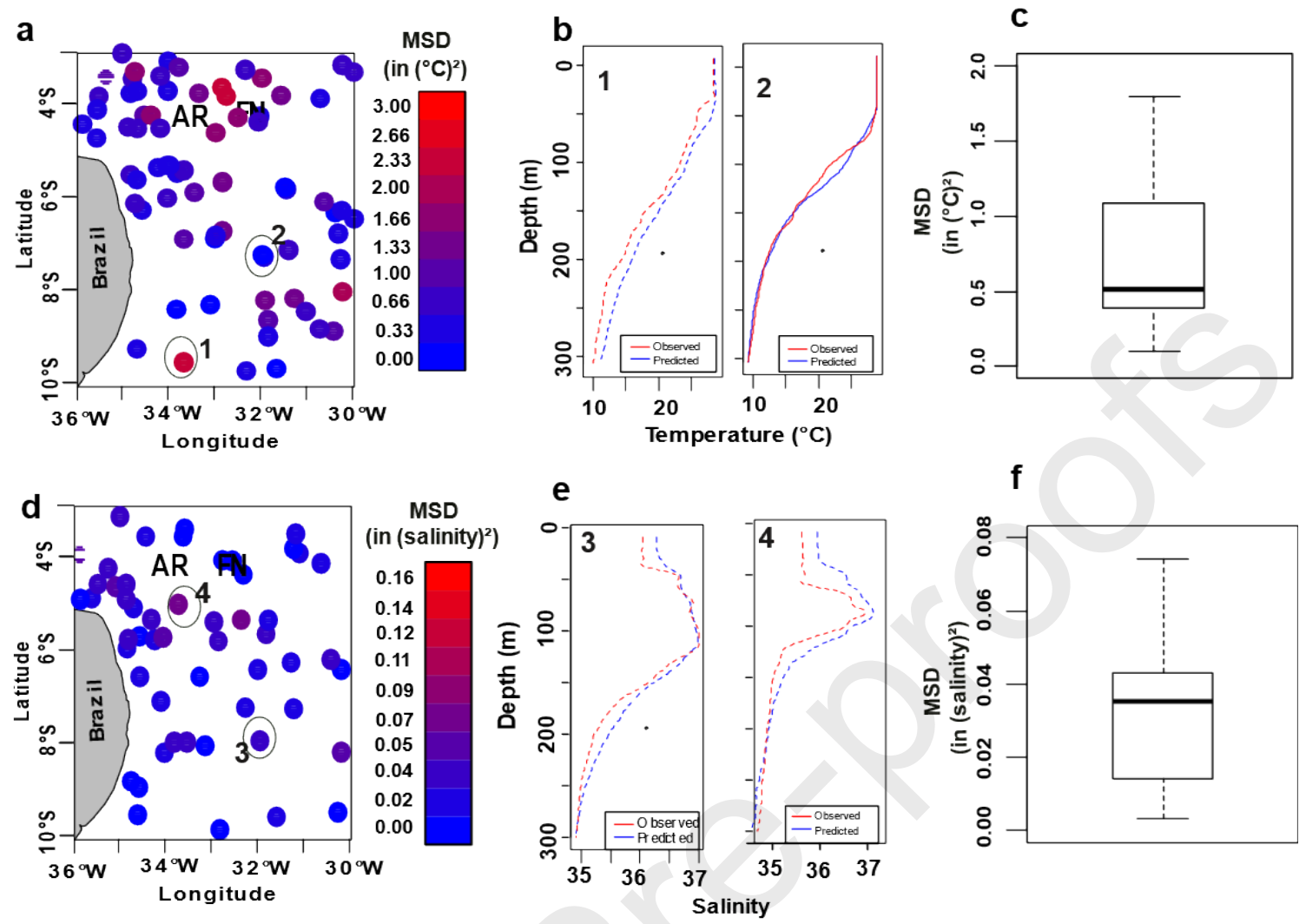

Figure S2. Validation for Functional Ordinary Kriging of temperature $\left({ }^{\circ} \mathrm{C}\right)(\mathrm{a}, \mathrm{b}, \mathrm{c})$ and salinity $(\mathrm{d}, \mathrm{e}, \mathrm{f})$ in fall using the Mean Square Difference (MSD). Maps of the distribution of the MSD for all stations for temperature (a) and salinity (b). Examples or good (2 and 3) and worst (1 and 4) predictions for temperature (b) and salinity (e). The corresponding profiles are circled in (a) and (d). The red lines correspond to the observations and the blue line to the predictions. The boxplots of the MSD for temperature (c) and salinity (f) are presented to evaluate the global performance of the estimators. 

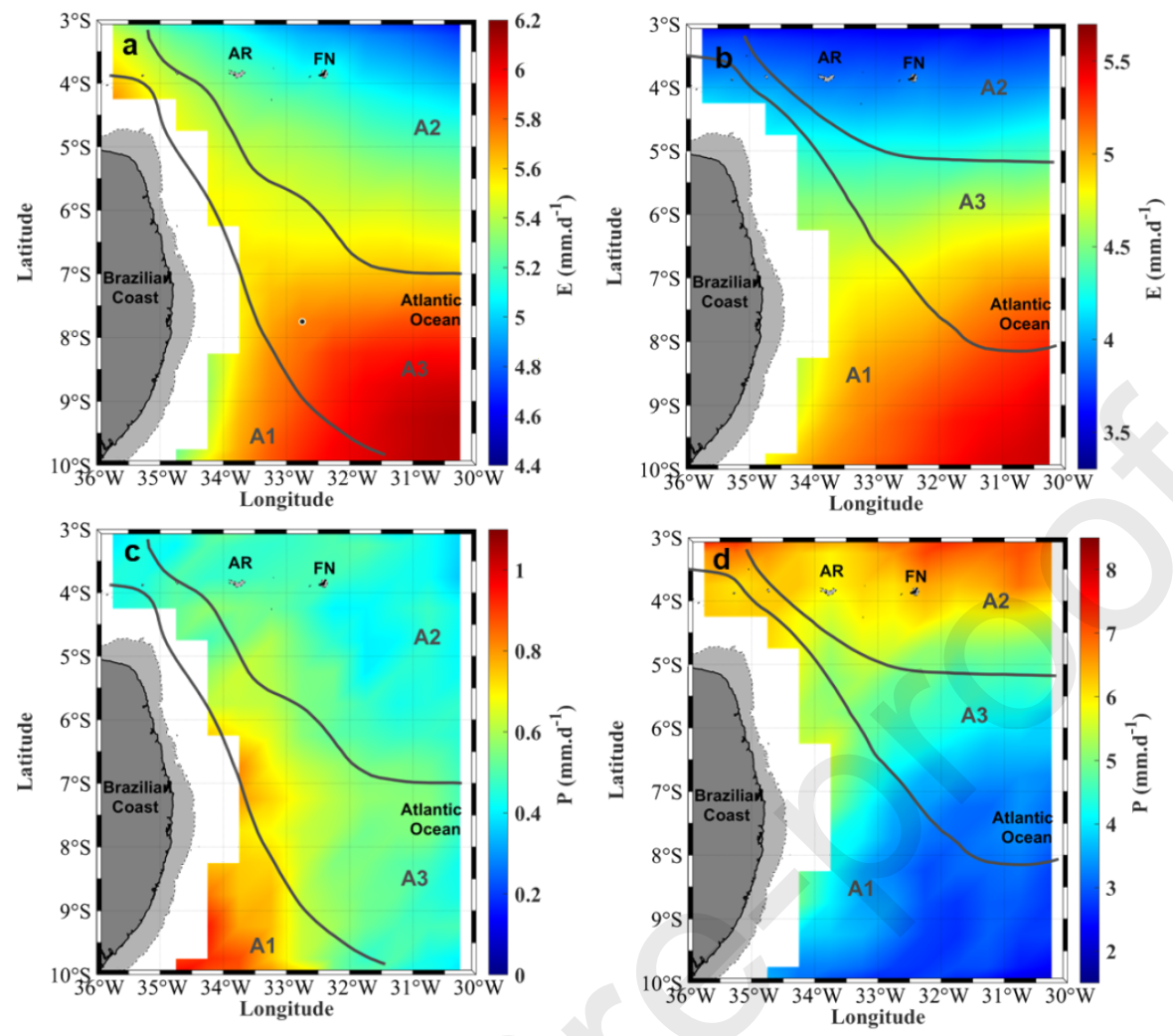

Figure S3. Evaporation and Precipitation in spring (a, c) and fall (b, d) according to HOAPS data for 1988 to 2014 in the southwestern tropical Atlantic. Grey solid lines delimit areas A1, A2 and A3 defined in section 3.2. The continental shelf limited by the isobaths of $60 \mathrm{~m}$ is represented by light grey. RA: Rocas Atoll; FN: Fernando de Noronha archipelago. Note that the scales vary between stations to highlight spatial variations. 

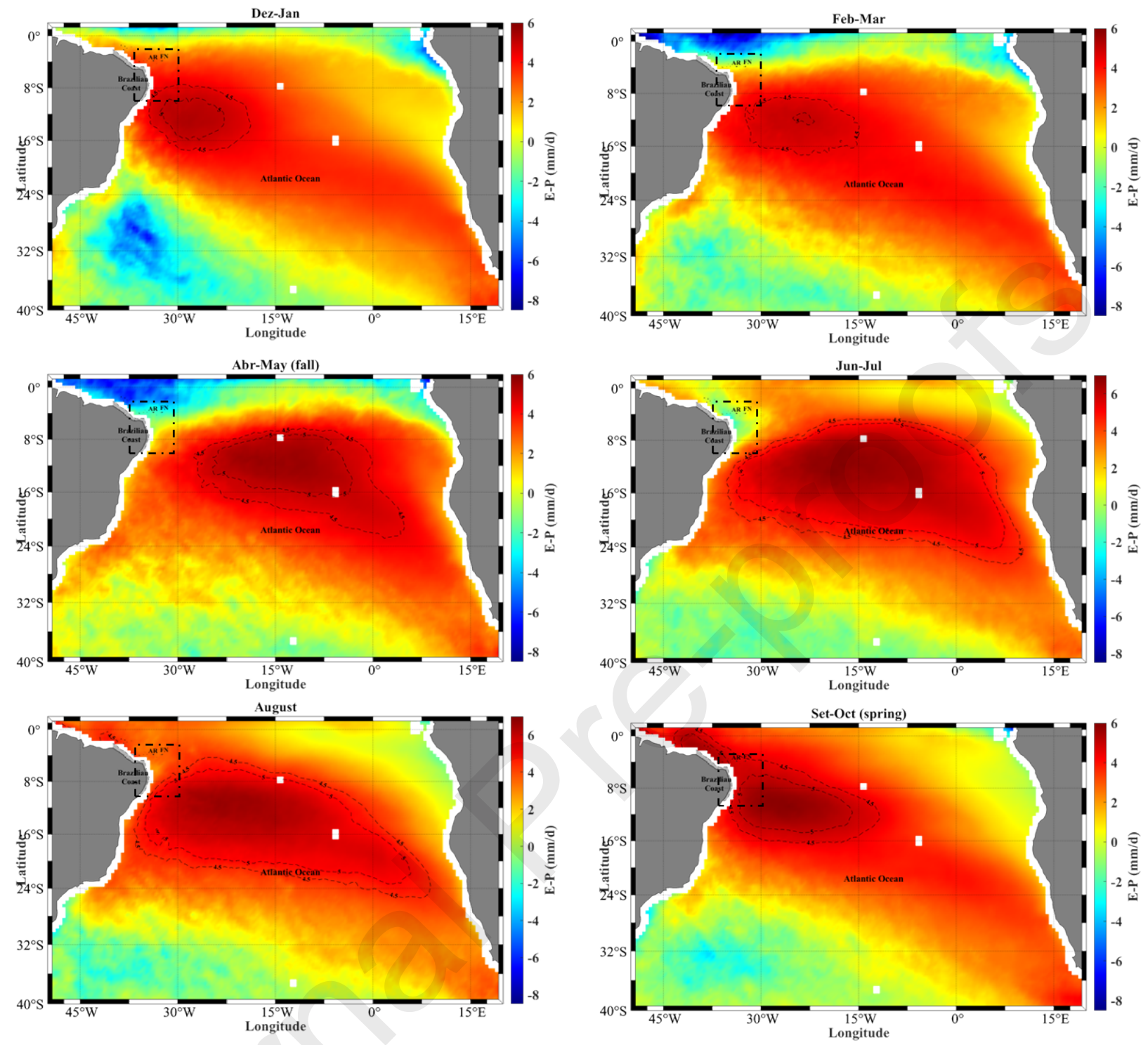

Figure S4. Seasonal climatology of evaporation minus precipitation budget (E-P) in the south Atlantic according to HOAPS data for 1988 to 2014. The dotted rectangle highlights the southwestern tropical Atlantic (study area). The dotted lines ( $\mathrm{E}-\mathrm{P}=4.5$ and $\left.5.0 \mathrm{~mm} \cdot \mathrm{d}^{-1}\right)$ highlight the region of high evaporation. 


\section{Highlights}

- The thermohaline structure drives most near surface oceanic processes

- A functional data analysis approach is used to characterise in 3D the thermohaline structure of the southwestern tropical Atlantic in spring and fall

- We reveal a clear spatial pattern with the presence of three areas with significantly different thermohaline structure

- The picture provided can serve as a reference for diagnosing future variation in the Atlantic Meridional Overturning Circulation

\section{$\bullet$}

\section{Declaration of interests}

$\bigotimes$ The authors declare that they have no known competing financial interests or personal relationships that could have appeared to influence the work reported in this paper.

$\square$ The authors declare the following financial interests/personal relationships which may be considered as potential competing interests: 